Pacific Northwest National Laboratory

Operated by Battelle for the

U.S. Department of Energy

\title{
Release Data Package for Hanford Site Assessments
}

\author{
R. G. Riley \\ C. A. Lo Presti \\ D. W. Engel
}

July 2006

Prepared for the U.S. Department of Energy under Contract DE-AC05-76RL01830 


\title{
DISCLAIMER
}

This report was prepared as an account of work sponsored by an agency of the United States Government. Neither the United States Government nor any agency thereof, nor Battelle Memorial Institute, nor any of their employees, makes any warranty, express or implied, or assumes any legal liability or responsibility for the accuracy, completeness, or usefulness of any information, apparatus, product, or process disclosed, or represents that its use would not infringe privately owned rights. Reference herein to any specific commercial product, process, or service by trade name, trademark, manufacturer, or otherwise does not necessarily constitute or imply its endorsement, recommendation, or favoring by the United States Government or any agency thereof, or Battelle Memorial Institute. The views and opinions of authors expressed herein do not necessarily state or reflect those of the United States Government or any agency thereof.

\author{
PACIFIC NORTHWEST NATIONAL LABORATORY \\ operated by \\ BATTELLE \\ for the
UNITED STATES DEPARTMENT OF ENERGY under Contract DE-AC05-76RL01830

Printed in the United States of America
Available to DOE and DOE contractors from the Office of Scientific and Technical Information, P.O. Box 62, Oak Ridge, TN 37831-0062; ph: (865) 576-8401 fax: (865) 576-5728
email: reports@adonis.osti.gov

\author{
Available to the public from the National Technical Information Service, \\ U.S. Department of Commerce, 5285 Port Royal Rd., Springfield, VA 22161 \\ ph: (800) 553-6847 \\ fax: (703) 605-6900 \\ email: orders@ntis.fedworld.gov \\ online ordering: http://www.ntis.gov/ordering.htm
}




\title{
Release Data Package for Hanford Site Assessments
}

\author{
R. G. Riley \\ C. A. Lo Presti \\ D. W. Engel
}

July 2006

Prepared for

the U.S. Department of Energy

under Contract DE-AC05-76RL01830

Pacific Northwest National Laboratory

Richland, Washington 99352 


\section{Preface}

This data package was originally prepared to support a 2004 composite analysis (CA) of low-level waste disposal at the Hanford Site. The Technical Scope and Approach for the 2004 Composite Analysis of Low-Level Waste Disposal at the Hanford Site (Kincaid et al. 2004) identified the requirements for that analysis and served as the basis for the data collection effort documented in this data package. Completion of the 2004 CA was later deferred, and the 2004 Annual Status Report for the Composite Analysis of Low-Level Waste Disposal in the Central Plateau at the Hanford Site (DOE 2005) indicated that a comprehensive update to the CA was in preparation and would be submitted in 2006.

However, the U.S. Department of Energy (DOE) has recently decided to further defer the CA update and will use the cumulative assessment currently under preparation for the environmental impact statement (EIS) being prepared for tank closure and other site decisions as the updated CA. Submittal of the draft EIS is currently planned for FY 2008. 


\section{Summary}

Beginning in fiscal year (FY) 2003, the U.S. Department of Energy (DOE) Richland Operations Office initiated activities, including the development of data packages, to support a Hanford assessment. This report describes the data compiled in FY 2003 through 2005 to support the Release Module of the System Assessment Capability (SAC). This work was completed as part of the Characterization of Systems Project managed by Pacific Northwest National Laboratory.

The Release Module applies release models to waste inventory data from the Inventory Module and accounts for site remediation activities as a function of time. The resulting releases to the vadose zone, expressed as time profiles of annual rates, become source terms for the Vadose Zone Module. Radioactive decay is accounted for in all inputs and outputs of the Release Module. The Release Module is implemented as the VADER (VADose zone Environmental Release) computer code. Key components of the Release Module are numerical models (i.e., liquid, soil-debris, cement, saltcake, and reactor block) that simulate contaminant release from the different waste source types found at the Hanford Site. The Release Module also handles remediation transfers to onsite and offsite repositories.

Each numerical model requires key parameter data to perform simulations of contaminant release from the different waste sources. This data package contains all the key parameter data necessary for implementation of the Release Module for conduct of the Hanford assessment.

A number of decisions were made that affect Release Module implementation for a Hanford assessment:

- Naval reactor compartments are excluded as a source of contaminant release (Appendix A).

- Chlorine-36 is excluded as a subsurface source of release to the atmosphere (Appendix B).

- Carbon-14 release to the atmosphere is accounted for from subsurface waste but iodine-129 is excluded as a contributor to the atmospheric pathway from buried waste (Appendix C).

- Contaminant release from immobilized low-activity waste is to be simulated using release simulations from the contractor performing analyses of the Integrated Disposal Facility.

- Contaminant release from tank waste residuals is to be simulated using the cement model as opposed to the saltcake model used in previous assessments. This allows complete consistency with tank waste residual release modeling associated with ongoing tank farm closure assessments. Simulations may be conducted with the saltcake model as a sensitivity analysis.

- No credit is taken for the effects of cardboard, wood or metal boxes on the initiation of contaminant release from waste sources. 


\section{Acronyms}

DOE

FY

GOSPL

HIC

ILAW

LLW

$\mathrm{RL}$

SAC

STOMP

STORM

VADER

WIDS
U.S. Department of Energy

fiscal year

Geographic and Operational Site Parameters List

High-integrity container

immobilized low-activity waste

low-level waste

DOE Richland Operations Office

System Assessment Capability

Surface Transport Over Multiple Phases

Subsurface Transport Over Reactive Multiphases

VADose zone Environmental Release

Waste Information Data System 


\section{Contents}

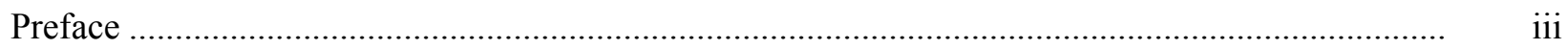

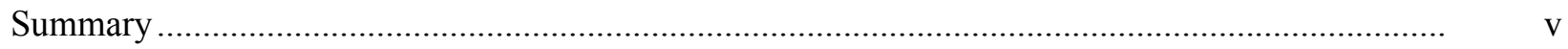

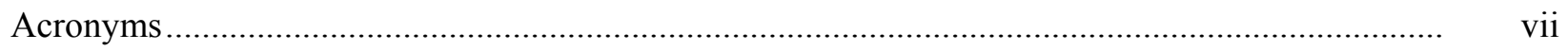

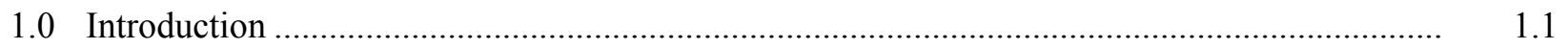

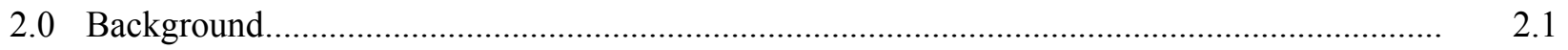

2.1 General Conceptual Model of Contaminant Release from Engineered Waste Systems .... $\quad 2.1$

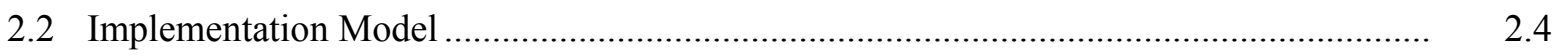

2.2.1 Assumptions and Limitations ..................................................................... 2.5

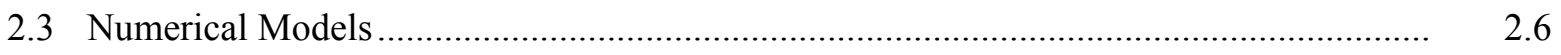

2.3.1 Assignment of Numerical Models to Specific Waste Types................................. 2.6

2.3.2 Analytical Solution: Liquid Release Model ...................................................... 2.6

2.3.3 Analytical Solution: Soil-Debris Model............................................................ 2.7

2.3.4 Analytical Solution: Cement Model .................................................................. 2.8

2.3.5 Analytical Solution: Saltcake Model.................................................................... 2.9

2.3.6 Analytical Solution: Reactor Block Model ...................................................... 2.9

2.3.7 Modeling Release from ILAW ...................................................................... 2.10

2.3.8 Modeling Release to the Atmospheric Pathway................................................. 2.10

2.3.9 Modeling the Effects of Waste Containment .................................................... 2.11

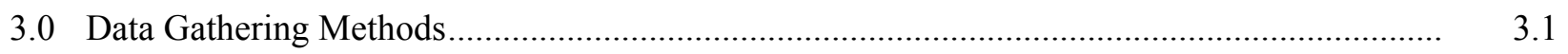

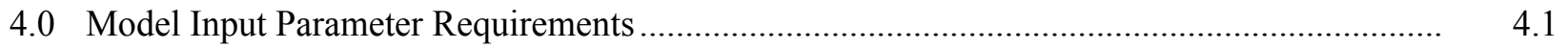

5.0 Proposed Input Parameter Values and Distributions .......................................................... 5.1

5.1 Liquid Release Model ......................................................................................

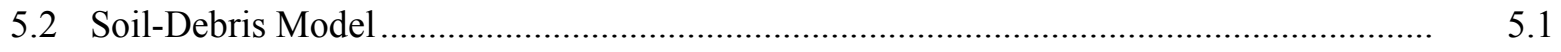

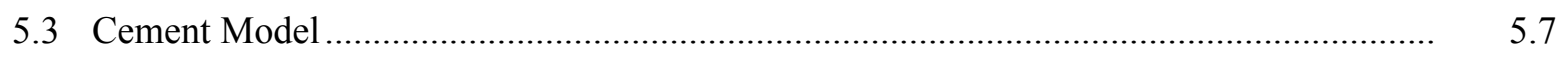

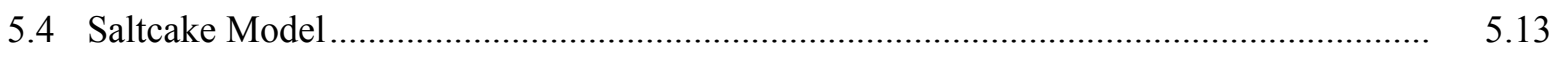

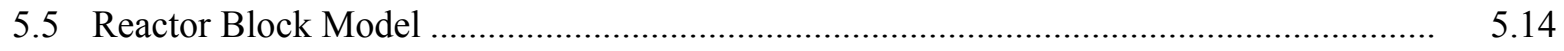

5.6 Modeling Release from ILAW ............................................................................ 5.15

5.7 Atmospheric Release Modeling ............................................................................ 5.15

6.0 Parameter Uncertainties, Data Gaps, Technical Issues, and Recommendations ...................... 6.1

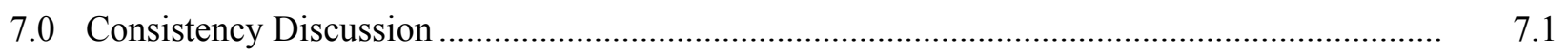

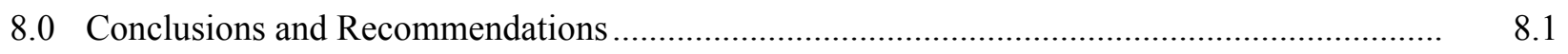

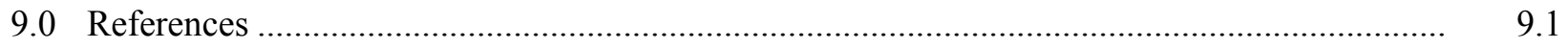

Appendix A - Technical Justification for Exclusion of the Naval Reactor Compartments as
Sources of Contaminant Release........................................................................... A.1

Appendix B - Justification for Exclusion from Consideration of Chlorine-36 as a Subsurface Source of Release to the Atmosphere .................................................................... B. B. 
Appendix C - Justification for Exclusion of Consideration of Iodine-129 as a Subsurface

Source of Release to the Atmosphere ...................................................................... C.

Appendix D - Henry's Law Constants for Carbon and Iodine .................................................. D.1

\section{Figures}

2.1 Data Input and Output from the Release Module ................................................................. 2.1

2.2 Basic Features of a Waste Containment Facility .................................................................... 2.2

2.3 Characteristics of Release Implementation Model ............................................................... 2.4

\section{Tables}

2.1 Summary of Release Model Assignments to Waste Source Types .......................................... 2.7

3.1 Summary of Location of Parameter Values Supporting Release Models................................... 3.2

4.1 Summary of Input Parameter Requirements for Release Models.............................................. 4.1

5.1 Summary of Cross-Sectional Area and Depth/Height Data for Application in the Soil-Debris Model for Burial Grounds ................................................................................... 5.2

5.2 Summary of Site Depth/Height and Cross-Sectional Areas for Application in the Soil-Debris Model .....

5.3 Calculated Values of Bulk Density and Volumetric Moisture Content for Application in the Soil-Debris Model ................................................................................................ 5.7

5.4 Waste Chemistry/Source Category 4: Low Organic/Low Salt/Near Neutral ............................ 5.8

5.5 Waste Chemistry/Source Category 2: Very High Salt/Very Basic........................................... 5.8

5.6 Analyte Aqueous Solubility Values and Interconversions ................................................... 5.9

5.7 Summary of Waste Source A/V Ratios for Sources Requiring Cement Release Model for Hanford Assessment Runs .......................................................................................... 5.10

5.8 Diffusion Coefficient Values for a Hanford Assessment High-Level Tank Waste Solid Residuals and Cement or Cement-Containing Waste Sources

5.9 Fractional Release Rates Available for Use in Reactor Block Model for a Hanford Assessment .....

6.1 Stochastic Treatment of Release Model Parameters Expected to be Implemented in a Hanford Assessment 


\subsection{Introduction}

This is the data package for the Release Module of the System Assessment Capability (SAC) that will be used to conduct Hanford assessments. The document includes a description of the Release Module and its association to the other SAC modules, a conceptual model for contaminant release from engineered waste systems represented by the Release Module, an implementation model that describes key input parameters and outputs of the numerical models that make up the Release Module, and descriptions of the numerical models used to simulate contaminant release from specific waste sources. The input parameters for the numerical models are described and the data to be used in a Hanford assessment are summarized in tables. Parameter uncertainty is discussed along with technical issues needing resolution to continue to improve the release model capability. 


\subsection{Background}

The Release Module of SAC (known hereafter as Release Module) applies release models to waste inventory data from the SAC Inventory Module and accounts for waste transfers conducted in the context of site remediation activities as a function of time. The resulting releases to the vadose zone, expressed as time profiles of annual rates, become source terms for the SAC Vadose Zone Module. Radioactive decay is accounted for in all inputs and outputs of the Release Module. The Release Module is implemented as the VADER (VADose zone Environmental Release) Revision 1 computer code (Figure 2.1) (Eslinger et al. 2004).

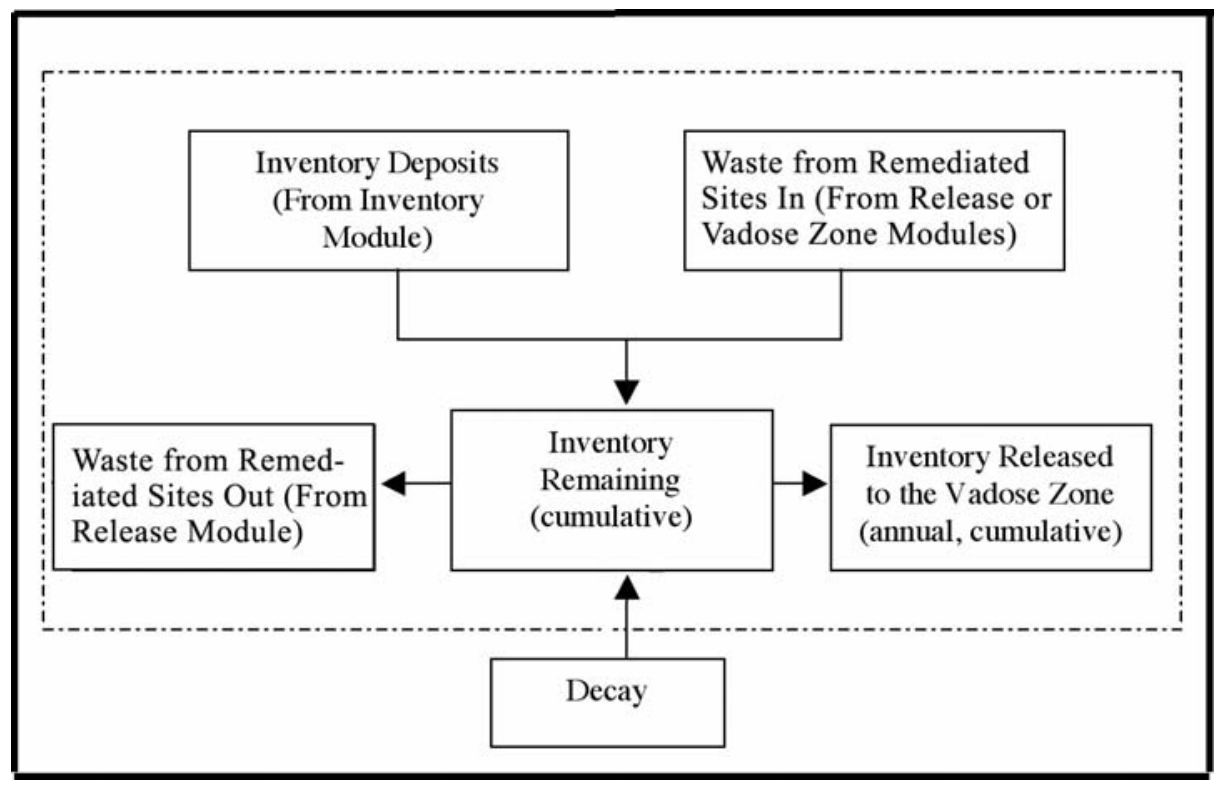

Figure 2.1. Data Input and Output from the Release Module (VADER)

\subsection{General Conceptual Model of Contaminant Release from Engineered Waste Systems}

The Release Module simulates contaminant releases from Hanford during operational periods (i.e., during years of plutonium production and radioactive waste reprocessing) and post operational periods (i.e., during cleanup and closure of the Hanford Site). During operational periods, large volumes of liquid waste were discharged to the ground or released to the Columbia River. Hanford waste containing contaminants of concern was also disposed in engineered systems during operational and post-operational periods.

Engineered waste systems have a number of features that influence the rate at which contaminants can be released from waste. Those features are illustrated in Figure 2.2. Note that an effort has been made to provide detail on features of engineered systems in this section recognizing that not all of these features are addressed in SAC assessment modeling (e.g., the effects of liners at the bottom of a burial ground like ERDF are not modeled in SAC at this time except as a time delay on release). Waste may be placed in some form of trench or reside in a tank. A tank or other form of engineered structure 


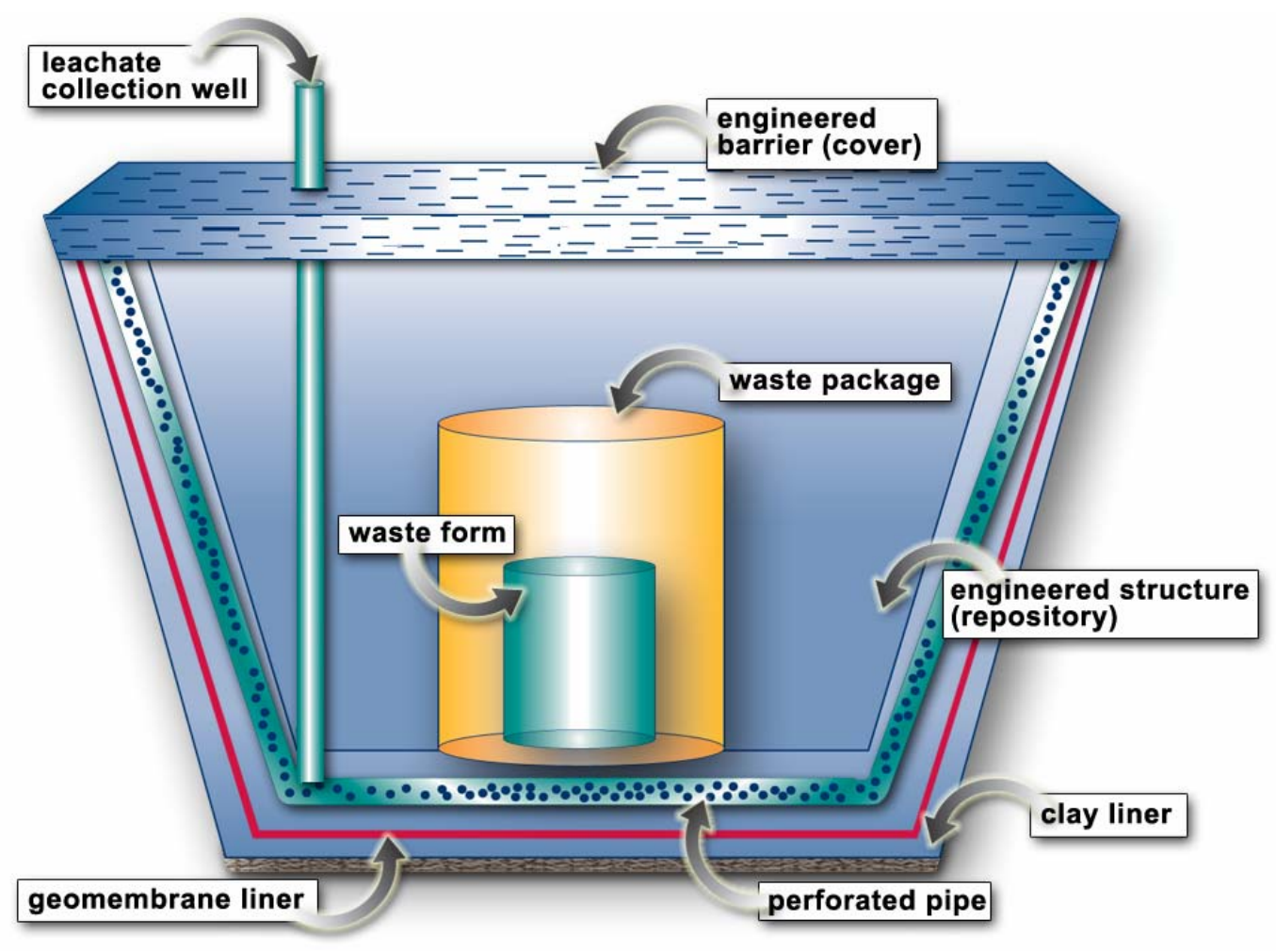

Figure 2.2. Basic Features of a Waste Containment Facility

(e.g., surface cover) serves as a barrier to infiltrating water so that the rate at which water contacts waste is reduced or delayed and the release of contaminants from the waste to the vadose zone is also reduced or delayed. Waste inside an engineered system (e.g., trench) may also be contained in a waste package (e.g., metal drum, cardboard or wooden boxes, or high integrity concrete container; Duncan et al. 1995). Drums or concrete containers, in particular, act as barriers to the release of the contaminants from the waste. Major engineered systems and waste package materials for Hanford waste are concrete, steel, and bituminous layers and coatings. The stability of these materials influences the length of time before infiltrating water contacts the waste or waste form and contaminants become available for release. Surface covers atop an engineered system (Meyers and Duranceau 1994; DOE 1996) and liners (geomembrane and clay) and leachate collection systems at the bottom of engineered systems further restrict the ability of infiltrating water to transport contaminants to the vadose zone (40 CFR 258.40; EPA 1997). Surface covers play a particularly important role because migration of infiltrating pore water will be limited as long as the cover maintains its integrity.

A number of key physical and chemical processes govern how much contaminant at any given time is released from the waste to the infiltrating water (Serne and Wood 1990). One process is the affinity of contaminants to be retained by the waste (e.g., by sorption to soil or waste material). Another process involves the ability of waste or waste forms to dissolve and, in some cases, form new precipitates allowing some contaminants to be released to the infiltrating water while other contaminants remain trapped in the precipitated solids. Release from the waste and precipitated secondary minerals would be limited by the solubility of the contaminant in the infiltrating water. Abiotic and biotic degradation of organic contaminants may occur while part of the waste or during transport limiting the amount of contaminant reaching the vadose zone. 
Water infiltrating an engineered system (e.g., high-level waste tank) may contact and react with fill materials (e.g., soil, basalt, grout) (McGrail et al. 2001) and with containment materials in various states of degradation, and with different types of waste. Reaction with these materials will result in changes to the chemistry of the water over time. Its composition, $\mathrm{pH}$, and redox state at any given time will influence the extent to which the processes described in the previous paragraph influence contaminant release from the waste.

Pore water migration into an engineered system is controlled by the permeability of a critical layer comprising the cover atop the engineered system or by a capillary break created by fine strata overlying coarse strata. Critical layers include synthetic geomembranes associated with regulatory compliant covers or layers that overcome some of the deficiencies associated with these covers (i.e., asphalt layers with bituminous coatings). The ability of the cover to minimize pore water migration will be a function of the quality of the installation (no leakage as the desirable feature) and the stability of the critical layer or layers over time. The long-term stability of these covers is unknown (Meyers and Duranceau 1994).

Contact between migrating water and the waste is delayed if the waste is contained in a repository (e.g., tank, vault, high integrity container) or waste package. Materials comprising these structures include concrete, steel, bituminous coatings, wood, and cardboard. The corrosive characteristic of the soil is a key factor in determining concrete and steel stability (Pihlajavaara 1994; Escalante 1989). The potential for carbonate mineral formation in the waste material also influences concrete stability (Walton et al. 1997). The stability of lignocellulosic containment materials (wood and cardboard) is controlled by the susceptibility of these materials to abiotic and biotic degradation processes or imposed physical processes (i.e., indiscriminate disposal practices and subsidence control that lead to loss of containment integrity). Crude disposal practices have resulted in significant loss of containment integrity for waste disposed in wood and cardboard containers (Duncan et al. 1995). However, subsurface conditions at Hanford would suggest that some containment materials (concrete in canyon building foundations) would be relatively stable over time (i.e., thousands to tens of thousands of years-Pihlajavaara, 1994), and, therefore, would be important features to consider in modeling contaminant release in long-term assessments from engineered burial grounds that contain such a feature..

Release of contaminants from waste to migrating pore water is influenced by specific waste features. Important features include such things as waste stability or ability to maintain structural integrity; structural and compositional makeup of the waste (i.e., the degree of homogeneity or heterogeneity); number, type, concentration of contaminants; and permeability. Processes that influence release from the waste to the migrating pore water include desorption, diffusion (e.g., diffusion out of permeable waste such as sludge or grout), solubility, solid phase dissolution/precipitation, chemical affinity, and corrosion.

Pore water (leachate) containing contaminants released from the waste eventually reaches the engineered system boundary within the vadose zone. At the boundary, a leachate collection system, followed by a geomembrane liner, followed by a synthetic clay liner are the final barriers to release of the contaminants from the engineered system to the vadose zone. Collected leachate moves into a sump where it is pumped out of the engineered system. For an optimized system, migration of the contaminated pore water is controlled by the low hydraulic conductivity properties of the geomembrane liner and the effective diffusion of contaminants through the geomembrane materials (e.g., diffusion in the pore water moderated by sorption) (40 CFR 258.40). Leakage in the geomembrane liner component of such systems is known to occur often during their installation (predominantly at seams) (Bonaparte and Gross 1990). Under these conditions, migration of contaminants that pass through these breaches is then 
controlled by restricted migration in the geosynthetic clay layer (EPA 1997). It is desirable that the net infiltration rate through a surface cover is less than the potential leak rate through the liner system.

\subsection{Implementation Model}

The Release Module accounts for releases that occurred in the early years of Hanford Site operations and those that may be expected while the Hanford Site is remediated over the next several decades and beyond. The Release Module relies on several sources of input (Figure 2.3). Input from the Inventory Module consists of contaminant mass and activity deposits, time history (i.e., year of deposit), waste volume, when remediation transfers occur, and radioactive decay. Some of the release models (i.e., soildebris, cement) require site-specific or waste feature information (i.e., site cross-sectional area, site volume, or waste surface area and volume). Recharge or infiltration rate is an important parameter to the saltcake and soil-debris models. Key process parameters are partition coefficient and contaminant solubility (soil-debris model), matrix solubility (saltcake model), diffusion coefficient (cement model) and fractional release rate (reactor block model).

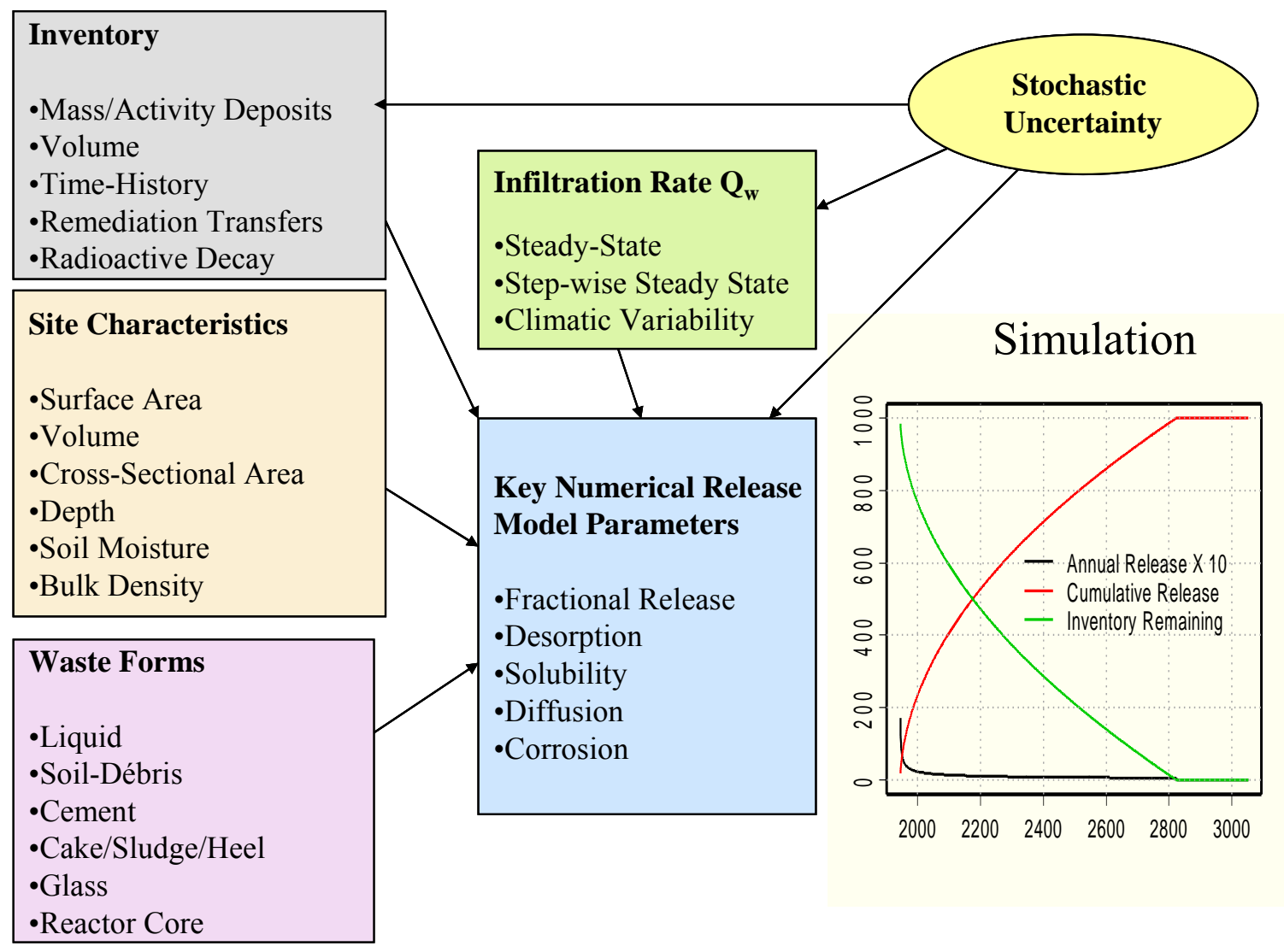

Figure 2.3. Characteristics of Release Implementation Model

A delay in the initiation of contaminant release can be applied to those waste types in some form of metal or concrete containment structure. For both types of containment, simple corrosion models are used to estimate the length of the delay. 


\subsubsection{Assumptions and Limitations}

For a Hanford assessment, a number of assumptions have been made in the implementation model that result in a simplification of the model:

- Beyond the timing and magnitude of infiltration rates, the implementation model will not include the effects of waste containment (e.g., steel liners in tanks, drums, high-integrity containers [HICs], or geomembrane and/or geosynthetic clay liners) on contaminant release from waste. It is expected that this assumption will result in more conservative (faster release) estimates. Included in the timing of infiltration is the potential delay assigned because of containment integrity.

- Contaminant release from surplus production reactor cores is assumed to occur according to a simple linear fractional release rate, ignoring the complex features of the core and their influence on contaminant release. This assumption is conservative in that recognition of the containment properties of the core would result in slower release rates (less conservative).

- Contaminants will be released from tank waste by the diffusion-controlled mechanism (cement model) assuming all the waste is sludge or hard heel because saltcake waste will have been removed during the waste recovery process. It is expected that this assumption will result in less conservative (slower release) but more realistic estimates.

- The waste source requiring the application of a model to simulate the release of contaminants from Naval reactor compartments is excluded because it was determined that the contaminants would not release from this waste during the length of time of this assessment (see Appendix A for details).

- Chlorine-36 is excluded as a subsurface source of release to the atmosphere (Appendix B). Carbon-14 release to the atmosphere is accounted for from subsurface waste but iodine-129 is excluded as a contributor to the atmospheric pathway from buried waste (Appendix C).

- All release model parameters except infiltration are treated as constant (within each realization) over the full simulation period.

- Infiltration rate time profiles for soil-debris waste will be varied over simulation realizations to reflect uncertainty in water infiltration. However, infiltration rates within time periods representing varying ground cover will be held constant over all realizations.

- Outputs from the analysis of the Integrated Disposal Facility by Fluor Federal Services are used as input to the Vadose Zone Module of SAC for simulating contaminant release from waste immobilized in glass.

- Liquid releases to the ground and the river will be treated as instantaneous releases at time of deposit (pass-through model) to the vadose zone and the Columbia River, respectively.

- Transfer of waste during remediation activities will be treated as if it was completed within one year, even though in practice the transfer could require multiple years. When actual remediation transfers at a site require multiple years to complete, the convention is to assign the transfer to the year the entire waste transfer is completed or scheduled to be completed. SAC software could be used to 
model a multiple year remedial action by means of multiple remedial action declarations for each year, but this is not used in the current assessments.

- Waste sources that apply the cement model assume a waste form that maintains structural integrity over the period of release (i.e., the surface area-to-volume ratio of the waste remains constant). Calculated surface areas are external and structures are assumed to be solid i.e., there is no distinction between waste that is a true waste form or hollow concrete structure (e.g., buildings or tunnels that contain contamination). It is assumed that all void spaces within a structure are filled to provide volume stability during final remedial actions.

\subsection{Numerical Models}

This section describes analytical solutions for each release model. Information is also provided on the issues of atmospheric release from subsurface waste and containment.

\subsubsection{Assignment of Numerical Models to Specific Waste Types}

Table 2.1 summarizes the release models that will be applied to the various waste site types identified in a Hanford assessment. Specific conditions for modeling some of the sites are described in the footnotes. Data sets are site specific. Equations are shown without a radioactive decay term for conceptual simplicity.

\subsubsection{Analytical Solution: Liquid Release Model}

Liquid releases are modeled as being dumped to the ground and instantly available to go into the vadose zone without retardation the year they enter the inventory (Eslinger et al. 2004). This is a passthrough, no decay, instantaneous release, and complete depletion release model. The loss of contaminant from the waste source as a function of time is given by:

$$
\mathrm{dM} / \mathrm{dt}=-\mathrm{MF}
$$

where $\mathrm{M}=$ current quantity of contaminant in the source zone (Ci or kg) or site inventory at time $\mathrm{t}$

$\mathrm{F}=$ fractional release rate $\left(\mathrm{y}^{-1}\right)$

When the fractional release rate is assigned the value of 1 , the entire inventory quantity is instantaneously released into the ground. The quantity of inventory released can be retarded by assigning a fractional release rate between 0 and 1 . The minus sign indicates that the quantity $\mathrm{dM} / \mathrm{dt}$ is to be subtracted from the inventory quantity $\mathrm{M}(\mathrm{t})$. 
Table 2.1. Summary of Release Model Assignments to Waste Source Types

\begin{tabular}{|c|c|}
\hline Release Model & Waste Source Type \\
\hline Liquid & $\begin{array}{l}\text { Past leaks and retrieval losses from single-shell tanks, }{ }^{(\mathrm{a})} \text { unplanned } \\
\text { releases }{ }^{(\mathrm{b})} \text { trenches, cribs, drain/tile fields, radioactive process sewers, } \\
\text { French drains, retention basins, ponds, ditches, sumps, injection/reverse } \\
\text { wells, storage tanks, diversion boxes, catch tanks, valve pits, settling tanks, } \\
\text { receiving vaults, neutralization tanks, and releases direct to the Columbia } \\
\text { River }\end{array}$ \\
\hline Soil-Debris & $\begin{array}{l}\text { Unplanned releases, }{ }^{(b)} \text { burial grounds, laboratories, storage, stacks, landfills, } \\
\text { surplus production facilities (i.e., the soil below and surrounding a facility), } \\
\text { sand filters }{ }^{(c)}\end{array}$ \\
\hline Cement & $\begin{array}{l}\text { Process unit/plants, control structures, storage tunnels, cemented waste in } \\
\text { burial grounds, single-shell tank residuals, }{ }^{(\mathrm{a})} \text { double-shell tank residuals }{ }^{(\mathrm{e})}\end{array}$ \\
\hline Saltcake & $\begin{array}{l}\text { Simulations of contaminant release from single-shell tank residuals may be } \\
\text { conducted with the saltcake model as a sensitivity analysis }\end{array}$ \\
\hline Reactor Block & Decommissioned surplus production reactor cores ${ }^{(\mathrm{d})}$ \\
\hline Glass & $\begin{array}{l}\text { Low activity waste (LAW) glass as well as category } 1 \text { low-level waste } \\
\text { (LLW), category } 3 \text { LLW, and mixed LLW in the Integrated Disposal } \\
\text { Facility (IDF) will be simulated in the updated Hanford assessment by } \\
\text { importing the IDF performance assessment base case release-to-water-table } \\
\text { file for all contaminants. }\end{array}$ \\
\hline \multicolumn{2}{|c|}{$\begin{array}{l}\text { (a) Releases from single-shell tanks will be modeled using a combination of liquid and cement models. Releases } \\
\text { may include past tank leaks, liquid released during retrieval, and contaminant release from dissolution of } \\
\text { residual solids following waste retrieval completion. } \\
\text { (b) Modeled as initial liquid release, release from a surface contaminated soil, or a combination of both. } \\
\text { (c) Site } 116-C-2 C \text { uses the liquid release model. } \\
\text { (d) No inventory releases occur from reactor cores post-operational period until they are relocated from the } \\
100 \text { Area to the Central Plateau. Inventory release from reactor cores buried on the Central Plateau begins in } \\
2065 \text {. }\end{array}$} \\
\hline
\end{tabular}

\subsubsection{Analytical Solution: Soil-Debris Model}

The soil-debris model postulates release of contaminants from inventory soil waste into a source zone. The complete soil-debris model implemented in VADER Revision 1 has two régimes: solubilitydriven and desorption-driven. When desorption would yield a contaminant concentration greater than the solubility limit, the model operates in the "solubility-controlled" mode, and the release rate depends on the magnitude of the solubility limit. When the concentration of a contaminant is less than the capacity of infiltrating water to dissolve, the quantity released depends on the infiltration rate, a partition coefficient (i.e., $\mathrm{K}_{\mathrm{d}}$ ) and soil characteristics (i.e., moisture content and bulk density), and is considered "desorptioncontrolled."

As an option, the soil-debris model as implemented in VADER can be operated in the solubilitydriven régime $\left(\mathrm{C}_{\text {sol }}\right.$ model $)$ without switching into desorption-driven mode. 
The rate of release of contaminant for a given contaminant by the soil-debris model is given by:

$$
\mathrm{dM} / \mathrm{dt}=-\mathrm{QAC}_{\mathrm{w}}
$$

where $\mathrm{C}_{\mathrm{w}}=\mathrm{C}_{\mathrm{sol}}$ effective concentration when the release process is solubility-controlled

$\mathrm{C}_{\mathrm{w}}=\mathrm{M} /(\theta \mathrm{RAh})$ effective concentration when the release process is desorption-controlled.

where $\mathrm{R}=1+\left(\beta \mathrm{K}_{\mathrm{d}}\right) / \theta$

Switching between régimes is controlled by comparing the remaining mass $\mathrm{M}(\mathrm{t})$ in the waste form with the maximum mass $\left(\mathrm{M}_{\max }=\theta \mathrm{RC}_{\mathrm{sol}} \mathrm{Ah}\right)$ possible to dissolve without a precipitated phase, consistent with an aqueous phase saturated with the contaminant.

If $\mathrm{M}(\mathrm{t})$ is larger than $\mathrm{M}_{\max }$, the release process is considered to be solubility controlled; otherwise it is desorption controlled. Under solubility-control, with constant $\mathrm{Q}_{\mathrm{w}}$ and $\mathrm{A}, \mathrm{dM} / \mathrm{dt}$ is constant. Under desorption-control, with constant $\mathrm{Q}_{\mathrm{w}}$ and $\mathrm{A}, \mathrm{dM} / \mathrm{dt}$ is steadily decreasing as $\mathrm{M}(\mathrm{t})$ is depleted:

where $\quad \mathrm{M}_{\max }=$ the maximum quantity of contaminant theoretically possible in the source zone (in $\mathrm{Ci}$ or $\mathrm{kg}$ ) without a precipitated phase

$\mathrm{M}=\mathrm{M}(\mathrm{t})$ is current quantity of contaminant contained in the source zone ( $\mathrm{Ci}$ or $\mathrm{kg})$

$\mathrm{Q}_{\mathrm{w}}=$ infiltration rate for the site in $\mathrm{cm} / \mathrm{yr}$; $\mathrm{Q}_{\mathrm{w}}$ can be considered constant, or considered to be time-dependent based on site climate, cover, and remediation activities

$\mathrm{A}=$ surface area of the soil waste form exposed to the release mechanism $\left(\mathrm{cm}^{2}\right)$

$\mathrm{h}=$ depth thickness or height of the soil waste form at the site $(\mathrm{cm})$

$\mathrm{C}_{\mathrm{w}}=$ a coefficient expressing the effective release concentration of the contaminant $\left(\mathrm{Ci} / \mathrm{cm}^{3}\right.$ or $\left.\mathrm{kg} / \mathrm{cm}^{3}\right)$

$\mathrm{C}_{\text {sol }}=$ expresses aqueous solubility of the contaminant in $\mathrm{Ci} / \mathrm{cm}^{3}$ or $\mathrm{kg} / \mathrm{cm}^{3}$

$\mathrm{R}=$ may be considered either a retardation factor or a soil apportionment factor (unitless) which depends on several factors:

B Soil bulk density in $\mathrm{g} / \mathrm{cm}^{3}$

$\mathrm{K}_{\mathrm{d}}$ Sorption factor $\left(\mathrm{cm}^{3} / \mathrm{g}\right)$

$\theta$ Volumetric content of water in soil (unitless fraction)

$\mathrm{dM} / \mathrm{dt}=$ the rate of loss of contaminant from the source zone (the rate contaminant crosses the soil waste form boundary and enters the environment)

$\mathrm{t}=$ the elapsed time (years) from the beginning of release from containment

\subsubsection{Analytical Solution: Cement Model}

The cement model is applied to waste that has the characteristics of cement, with the assumption that the contaminant is embedded homogeneously in the cement waste form. The total external surface area and volume of the waste form must be known. The ratio of surface area to waste volume is assumed to be constant, implying that the cement waste form maintains structural shape integrity over time. The structure is assumed to be a solid cementitious material. The most important term in the model is the diffusion coefficient. It describes the rate at which the contaminant migrates from the interior of the cement form to its surface. Once at the surface, $100 \%$ of the contaminant is assumed to leach into the migrating pore water. Release continues at a steadily decreasing rate until $\mathrm{M}(\mathrm{t})$ is completely depleted. The ratio of area to volume can also be a significant term in the diffusive release model. Care is taken to define $\mathrm{A} / \mathrm{V}$ for waste forms (e.g., containers) and not entire facilities (e.g., burial grounds or trenches). 
The rate of loss of contaminant for a given contaminant is given by:

$$
\mathrm{dM} / \mathrm{dt}=-\mathrm{M}_{\mathrm{o}}(\mathrm{A} / \mathrm{V})(\mathrm{D} / \pi \mathrm{t})^{1 / 2}
$$

where $\quad \mathrm{M}_{0}=$ the original quantity of the contaminant contained in the cement ( $\mathrm{Ci}$ or $\left.\mathrm{kg}\right)$. This can be seen as a function of concentration $\left(\mathrm{kg} / \mathrm{cm}^{3}\right.$ or $\left.\mathrm{Ci} / \mathrm{cm}^{3}\right)$ and volume $\left(\mathrm{cm}^{3}\right)$

$\mathrm{A}=$ the geometric surface area of the cement structure $\left(\mathrm{cm}^{2}\right)$

$\mathrm{V}=$ the volume of the cement structure $\left(\mathrm{cm}^{3}\right)$

$\mathrm{D}=$ the diffusion coefficient of the contaminant $\left(\mathrm{cm}^{2} / \mathrm{yr}\right)$

$\mathrm{t}=$ the elapsed time (years) from the beginning of release from containment

$\mathrm{dM} / \mathrm{dt}=$ the rate of loss of contaminant from the cement waste form as it is leached into the environment by infiltrating water

\subsubsection{Analytical Solution: Saltcake Model}

Historically, the saltcake model has been used to simulate contaminant release from tank waste solid residuals. When used, contaminants are assumed to be contained within a waste matrix termed saltcake, which is composed of saltcake, sludge, and heel without differentiation. The waste is assumed to be homogeneously distributed throughout the tank and the saltcake matrix is assumed to be mostly composed of nitrate salts (e.g., sodium nitrate). This saltcake is assumed to contain the contaminants that dissolve in percolating water congruently with the matrix. The saltcake model consists of a simple analytical solution containing a term for infiltration, matrix (nitrate) solubility, and the cross-sectional area of the waste source.

The release rate for a given contaminant is given by:

$$
\mathrm{dM} / \mathrm{dt}=-\mathrm{M}_{\mathrm{o}} \mathrm{A} \mathrm{Q}_{\mathrm{w}} C_{w o}^{\text {sol }} / \mathrm{M}_{\mathrm{wo}}
$$

where $\quad \mathrm{M}_{\mathrm{wo}}=$ the original mass of saltcake $(\mathrm{kg}) . \mathrm{M}_{\mathrm{wo}}$ may also be derived by the product of tank waste volume and waste density such that $\mathrm{M}_{\mathrm{wo}}$ equals $\mathrm{M}_{\mathrm{o}}$

$\mathrm{M}_{\mathrm{o}}=$ the original quantity of contaminant in $\mathrm{Ci}$ or kg embedded in the saltcake

$M=M(t)$ is the current quantity of the contaminant contained in the saltcake (Ci or kg) at time $\mathrm{t}$

$A=$ the surface area of saltcake exposed to the release mechanism $\left(\mathrm{cm}^{2}\right)$

$C_{\text {wo }}^{\text {sol }}=$ the aqueous solubility of the saltcake simulated as the concentration of nitrate (as nitrate salts) in tank supernate $\left(\mathrm{g} / \mathrm{cm}^{3}\right)$

$\mathrm{Q}_{\mathrm{w}}=$ the site recharge rate in $\mathrm{cm} / \mathrm{yr}$, also termed infiltration rate

$\mathrm{dM} / \mathrm{dt}=$ the rate of loss of contaminant from the saltcake waste form per unit time $\mathrm{t}$ (the rate at which the contaminant leaks from the tank into the environment)

\subsubsection{Analytical Solution: Reactor Block Model}

The reactor block model is used to simulate the release of contaminants from decommissioned production reactor cores on the Hanford Site. Reactor cores are composed of graphite, a material 
extremely resistant to corrosion and highly impermeable. The mechanism of contaminant release from reactor cores is not well understood. The analytical solution is simple, consisting of only a contaminant mass and fractional release term (DOE 1989).

The rate of loss of contaminant for a given contaminant is given by:

$$
\mathrm{dM} / \mathrm{dt}=-\mathrm{M}_{\mathrm{o}} \mathrm{F}_{\text {rrr }}
$$

where $\mathrm{M}_{\mathrm{o}}=$ the initial quantity in $\mathrm{Ci}$ or $\mathrm{kg}$ of contaminant in the graphite core

$\mathrm{F}_{\mathrm{rrr}}=$ the fractional release rate in $\mathrm{yr}^{-1} . \mathrm{F}_{\mathrm{rrr}}$ is analyte specific, and ranges from 0 to 1

This model generates a family of curves such that the smaller the value of $F_{\text {rrr }}$, the more elapsed time is required until a specific contaminant inventory is completely depleted from the graphite block. $\mathrm{M}_{\mathrm{o}}$ serves as a multiplier to calculate annual quantity released.

Carbon-14 is a special case because its release from graphite has been found to be strongly temperature-dependent. Therefore, a release model has been developed to allow the carbon-14 fractional release rate to vary as a function of time and reactor temperature during reactor operation, shutdown and cooling (ten year time frame), cocooning, and disposal on the Central Plateau. The analytical solution for the time and temperature dependent release of carbon-14 from reactor cores is represented numerically in the following expression (Kincaid et al. 1998):

$$
\mathrm{dM} / \mathrm{dt}=-\mathrm{M}_{\mathrm{o}}(365)\left[565\left(1+100 \mathrm{e}^{-(0.08)(365) t}\right) \mathrm{e}^{-6440 / \mathrm{T}}\right]
$$

where $\mathrm{M}_{\mathrm{o}}=$ the initial quantity in $\mathrm{Ci}$ of carbon-14 in the core

$\mathrm{T}=$ the absolute temperature of the reactor block $\left({ }^{\circ} \mathrm{K}\right)$

$\mathrm{t}=$ elapsed time in years since deposit year

While VADER contains the capability for temperature dependent release of carbon-14 from production reactor cores, the capability is not planned for application at this time to this waste source in future Hanford assessments. Carbon-14 release is based on application of a calculated fractional release rate (Table 5.9) applied to Equation (2.5).

\subsubsection{Modeling Release from ILAW}

A glass model is not applied within VADER to simulate contaminant release from immobilized lowactivity waste (ILAW) waste for the Hanford assessment. Instead, contaminant release from ILAW is simulated by importing IDF performance assessment base case release-to-top of water-table file for all contaminants.

\subsubsection{Modeling Release to the Atmospheric Pathway}

Atmospheric releases during operational time periods are simulated through the Inventory Module. Outputs of the Inventory Module are directed into an atmospheric dispersion model (Napier 2002; Napier and Ramsdell 2005).

Atmospheric release from subsurface disposed waste is managed through the Vadose Zone (STOMP) Module. Chlorine-36 and iodine-129 are excluded as a subsurface source of release to the atmosphere 
(Appendix B and Appendix C). STOMP simulates the release of carbon-14 to the soil surface from subsurface waste (Section 5.7). It is assumed that all the carbon-14 in the pore water of the subsurface is in the form of carbon dioxide $\left(\mathrm{CO}_{2}\right)$ as a basis for determining that portion of the $\mathrm{CO}_{2}$ present in the subsurface pore space using Henry's law constant (Appendix D). This output from STOMP becomes an input to the atmospheric transport and deposition model (RATCHET) (Napier and Ramsdell 2005).

\subsubsection{Modeling the Effects of Waste Containment}

The Release Module has the capability to account for the effects of metal and concrete containment on release of analytes from waste. Containment at Hanford includes steel liners in high-level waste tanks and low carbon steel drums, Naval reactor compartments and reactor vessels, ILAW canisters, and concrete HICs. Containment in the Release Module is expressed as a delay in the time of initiation of release of an analyte from the waste. The delay in release is calculated off-line using a corrosion model for both metal and concrete materials. The delay can be varied between simulation runs to account for stochastic variability. 


\subsection{Data Gathering Methods}

Mathematical formulas that express the release of contaminants from various waste sources, the parameters important to those formulations and associated parameter data, and their application in past Hanford assessments are documented in many reports published since 1987. Preparation and publication of an initial data catalog (Riley and Lo Presti 2001) was conducted under the Vadose Zone Groundwater Integration Project managed by Bechtel Hanford, Inc. for the DOE Richland Operations Office (RL). The initial data catalog 1) provided a summary of descriptions and uses of release models used in assessments from 1987 to 2001, 2) described analytical solutions for contaminant release from various types of waste sources and assessed their commonality, 3) linked release models to data on various waste sources found on the Hanford Site, and 4) provided listings of sources of parameter information and parameter data used in the models. For purpose four, the report provided links to specific pages, figures, and tables for locating specific information and data within documents. Information and data from the initial data catalog (Riley and Lo Presti 2001) was used in the preparation and application of a release data package for the conduct of the SAC initial assessment (Bryce et al. 2002).

The initial data catalog (Riley and Lo Presti 2001), with support from the Characterization of Systems Project managed by Pacific Northwest National Laboratory, has been updated (Riley and Lo Presti 2003). This updated data catalog presents a conceptual model of release and informs the reader of some of the key features and processes that influence contaminant release from Hanford waste sources. Additional applications of release models to assessments pertaining to ILAW and solid waste disposal sites are summarized. A section on the effects of containment on contaminant release from selected waste sources is included. The data catalog (Riley and Lo Presti 2003) excludes information on release by way of the atmospheric pathway. Information on release to the atmospheric pathway from near-surface waste sources was acquired from a number of reports that summarized previous Hanford assessments (DOE 1996 and 1989; Kincaid et al. 1995 and 1998; Wood et al. 1995 and 1996; Streile et al. 1996). Information and data from these reports, other more recent reports (Pierce et al. 2004; DOE 2005b) and the most recent data catalog (Riley and Lo Presti 2003) were sources for data summarized in Chapter 5. Table 3.1 summarizes the location of parameter values for release models supporting Hanford assessments (i.e., their location in the release data package and SAC electronic files [GOSPL]). Between assessments, changes that occur in parameter values or treatment are documented in Data Change Requests (DCRs). 
Table 3.1. Summary of Parameter Value Documentation Supporting Release Models

\begin{tabular}{|c|c|c|}
\hline Model/Parameter & Data Package & $\begin{array}{l}\text { Electronic File and } \\
\text { Records }^{(a)}\end{array}$ \\
\hline $\begin{array}{l}\text { Soil Debris/Cross sectional area and depth/height } \\
\text { values for burial grounds }\end{array}$ & Table $5.1^{(\mathrm{b})}$ & $\begin{array}{l}\text { GOSPL_2005-10-21- } \\
\text { DCR-0013.xls }\end{array}$ \\
\hline $\begin{array}{l}\text { Soil Debris/Cross sectional area and depth/height } \\
\text { values for selected waste sources }\end{array}$ & Table $5.2^{(\mathrm{b})}$ & $\begin{array}{l}\text { GOSPL_2005-10-21- } \\
\text { DCR-0013.xls }\end{array}$ \\
\hline $\begin{array}{l}\text { Soil Debris/Bulk density and volumetric moisture } \\
\text { content values }\end{array}$ & Table $5.3^{(\mathrm{b})}$ & $\begin{array}{l}\text { GOSPL_2005-10-21- } \\
\text { DCR-0013.xls }\end{array}$ \\
\hline Soil Debris/Partition coefficient values & $\begin{array}{l}\text { Tables } 5.4^{(\mathrm{b})} \text { and } \\
5.5^{(\mathrm{b})}\end{array}$ & $\begin{array}{c}\text { vadose_2006-01-25_DCR- } \\
\text { 0038.xls }\end{array}$ \\
\hline Soil Debris/Aqueous solubility values & Table $5.6^{(\mathrm{b})}$ & $\begin{array}{l}\text { GOSPL_2005-11-01- } \\
\text { DCR-0021.xls }\end{array}$ \\
\hline Soil Debris/Change ERDF start release & & $\begin{array}{l}\text { GOSPL_2005-10-28- } \\
\text { DCR-0019.xls }\end{array}$ \\
\hline $\begin{array}{l}\text { Soil Debris-Cement/Correct release parameter } \\
\text { values ("RelTab") }\end{array}$ & & $\begin{array}{l}\text { GOSPL_2005-11-01- } \\
\text { DCR-0021.xls }\end{array}$ \\
\hline $\begin{array}{l}\text { Soil Debris-Cement/Correct release parameter } \\
\text { values (prevent release from RMWSF) }\end{array}$ & & $\begin{array}{l}\text { GOSPL_2005-11- } \\
17 \_ \text {DCR-0026.xls }\end{array}$ \\
\hline $\begin{array}{l}\text { Soil debris/partition ERDF remedial routing } \\
(600-148 \text { _west (east)) }\end{array}$ & & $\begin{array}{l}\text { GOSPL_2006-01- } \\
\text { 13_DCR-0034.xls }\end{array}$ \\
\hline Cement/A/V ratio values & Table $5.7^{(\mathrm{b})}$ & $\begin{array}{l}\text { GOSPL_2005-10-21- } \\
\text { DCR-0013.xls }\end{array}$ \\
\hline Cement/Change A/V ratio values $(218-\mathrm{W}-4 \mathrm{C})$ & & $\begin{array}{l}\text { GOSPL_2005-10-21- } \\
\text { DCR-0013.xls }\end{array}$ \\
\hline Cement/Diffusion coefficient values & Table $5.8^{(\mathrm{b})}$ & $\begin{array}{l}\text { GOSPL_2005-10-21- } \\
\text { DCR-0013.xls }\end{array}$ \\
\hline Reactor Block/Fractional release rate values & Table $5.9^{(\mathrm{b})}$ & $\begin{array}{l}\text { GOSPL_2005-10-21- } \\
\text { DCR-0013.xls }\end{array}$ \\
\hline $\begin{array}{l}\text { Atmospheric Release Parameters-STOMP } \\
\text { Change I-129 to liquid phase only, Henry's Law } \\
\text { constants corrected }\end{array}$ & Table $5.10^{(\mathrm{b})}$ & $\begin{array}{l}\text { Analyte_2005-07- } \\
\text { 07_DCR-0001.xls } \\
\text { Analyte_2006-03- } \\
\text { 16_DCR-0049.xls }\end{array}$ \\
\hline $\begin{array}{l}\text { Saltcake/High-level waste tank cross sectional area } \\
\text { values }\end{array}$ & Table $5.9^{(\mathrm{c})}$ & $\begin{array}{l}\text { GOSPL_2005-10-21- } \\
\text { DCR-0013.xls }\end{array}$ \\
\hline Correct vadose zone template thicknesses & & $\begin{array}{l}\text { vadose_2006-01-25_DCR- } \\
\text { 0038.xls }\end{array}$ \\
\hline $\begin{array}{l}\text { Add } \mathrm{U} \text { isotopic solubilities, update areas, volumes, } \\
\text { and diffusion coefficients }\end{array}$ & & $\begin{array}{l}\text { GOSPL_2006-05- } \\
\text { 05_DCR-0054.xls }\end{array}$ \\
\hline $\begin{array}{l}\text { (a) File available from author. } \\
\text { (b) This report. } \\
\text { (c) Riley and Lo Presti (2004). } \\
\text { A/V = Area to volume ratio. } \\
\text { ERDF = Environmental Restoration Disposal F } \\
\text { GOSPL = Geographic and Operational Site Para } \\
\text { RMWSF = Radioactive Mixed Waste Storage Fac }\end{array}$ & lity. & \\
\hline
\end{tabular}




\subsection{Model Input Parameter Requirements}

Table 4.1 summarizes the key parameters associated with the numerical models described in Section 2.3. Parameter values for each of the models are discussed in Chapter 5.

Table 4.1. Summary of Input Parameter Requirements for Release Models

\begin{tabular}{|c|c|c|c|c|c|c|}
\hline \multirow[b]{2}{*}{ Model Parameter } & \multicolumn{6}{|c|}{ Release Model Type } \\
\hline & Liquid & $\begin{array}{c}\text { Soil- } \\
\text { Debris }\end{array}$ & Cement & Saltcake & $\begin{array}{l}\text { Reactor } \\
\text { Block }\end{array}$ & Glass $^{(a)}$ \\
\hline Cross-sectional area of source zone & & $\mathrm{X}$ & & $\mathrm{X}$ & & \\
\hline $\begin{array}{l}\text { Depth of waste or distance from soil } \\
\text { surface to bottom of contaminant } \\
\text { source zone }\end{array}$ & & $\mathrm{X}$ & & & & \\
\hline Distribution coefficient & & $\mathrm{X}$ & & & & \\
\hline Bulk density of soil & & $\mathrm{X}$ & & & & \\
\hline Volumetric moisture content of soil & & $\mathrm{X}$ & & & & \\
\hline Contaminant solubility & & $\mathrm{X}$ & & & & \\
\hline Matrix solubility & & & & $\mathrm{X}$ & & \\
\hline Fractional release rate & $\mathrm{X}$ & & & & $\mathrm{X}$ & \\
\hline Infiltration rate & & $\mathrm{X}$ & & $\mathrm{X}$ & & \\
\hline Waste density $^{(\mathrm{b})}$ & & & & $\mathrm{X}$ & & \\
\hline Waste surface area & & & $\mathrm{X}$ & & & \\
\hline Waste volume & & & $\mathrm{X}$ & & & \\
\hline Diffusion coefficient & & & $\mathrm{X}$ & & & \\
\hline $\begin{array}{l}\text { Mass of structural component in } \\
\text { source zone } \text { (b) }^{(2)}\end{array}$ & & & & $\mathrm{X}$ & & \\
\hline Mass or activity of contaminant & $\mathrm{X}$ & $\mathrm{X}$ & $\mathrm{X}$ & $\mathrm{X}$ & $\mathrm{X}$ & \\
\hline Temperature $^{(\mathrm{c})}$ & & & & & $\mathrm{X}$ & \\
\hline \multicolumn{7}{|c|}{$\begin{array}{l}\text { (a) Not applicable. Low-activity waste (LAW) glass as well as category } 1 \text { low-level waste (LLW), category } 3 \\
\text { LLW, and mixed LLW in the Integrated Disposal Facility (IDF) will be simulated in a Hanford assessment by } \\
\text { importing the IDF performance assessment base case release-to-top of water-table file for all contaminants. } \\
\text { (b) Because the Inventory Module provides the saltcake matrix of each tank as a volume, a saltcake matrix density } \\
\text { value is required to convert tank waste volumes to equivalent masses. Recent applications of the saltcake model } \\
\text { within the System Assessment Capability (SAC) have used a statistically derived value of density for tank } \\
\text { solids (Chen et al. 1998) based on tank characterization data. Typical density values are around } 1.5 \mathrm{~g} / \mathrm{cm}^{3} \text {. } \\
\text { (c) For temperature-dependent release of carbon-14 from graphite reactor cores. This capability is not currently } \\
\text { implemented for this waste source in a Hanford assessment. }\end{array}$} \\
\hline
\end{tabular}




\subsection{Proposed Input Parameter Values and Distributions}

This section summarizes the parameters and parameter data and other waste source data for numerical models described in Chapter 2. In many cases, values for parameter data in the tables of this section do not exactly reflect values in electronic data files used in SAC simulations. The number of significant digits in the electronic files is governed by the format of the input file based on the software design. As a result, some parameter values in this data package are truncated and rounded.

\subsection{Liquid Release Model}

Liquid releases are modeled as being discharged to the ground and instantly available to infiltrate into the vadose zone without retardation and decay, i.e., the year they enter the inventory (Eslinger et al. 2004). The instantaneous release is accomplished by assigning the model a fractional release rate of one. The liquid release model is also used to account for instantaneous releases directly to the Columbia River.

\subsection{Soil-Debris Model}

For a Hanford assessment, contaminant release from all burial grounds is simulated using the soildebris model. At some burial grounds, the cement model is used in combination with the soil-debris model. This recognizes that one or more burial grounds are assigned an inventory of stabilized waste (e.g., technetium-99 or iodine-129, and uranium in high-integrity concrete vaults or other form of concrete waste). Accounting for these inventories in this manner maintains consistency with previous Hanford assessments (Kincaid et al. 1998; Wood et al. 1995, 1996).

Source zone depth/height information is needed for all burial ground sites to run the soil-debris model. Some depth/height information has been obtained from the Waste Information Data System (WIDS) as provided by the Geographic and Operational Site Parameters List (GOSPL) (Last et al. 2004). An average depth/height $(5.3 \mathrm{~m})$ has been assigned based on the available WIDS data and applied to all burial ground sites that do not have a depth/height value. For one site, a default depth/height value of $0.999 \mathrm{~m}$ was applied. In a few instances, cross-sectional area values were not available, in which case a default value of $999 \mathrm{~m}^{2}$ is applied. These data are summarized in Table 5.1.

The soil-debris model is also applied to laboratory, storage, and stack-type waste sources. Available dimensional data on these sites are from the WIDS database. When waste source dimension information was missing, the waste source with missing data was compared to waste sources where dimension data were available to calculate and assign dimensions from which depths/heights and cross-sectional areas could be estimated. The soil-debris model has been applied to some of the unplanned release sites. Where cross-sectional area and depth/height information were missing, default values of $0.999 \mathrm{~m}^{2}$, $9.99 \mathrm{~m}^{2}$ or $99.9 \mathrm{~m}^{2}$ and $0.999 \mathrm{~m}$ were assigned for cross-sectional area and depth/height, respectively. This data set is summarized in Table 5.2.

Values for bulk density and volumetric moisture content for the 100, 200, and 300 Areas were calculated from available data (Peterson et al. 1996; Schalla et al. 1988; Fayer et al. 1999) at depths no greater than $6 \mathrm{~m}$ (i.e., the approximate maximum depth observed for burial grounds on the Hanford Site). Those data are summarized in Table 5.3. 
Table 5.1. Summary of Cross-Sectional Area and Depth/Height Data for Application in the Soil-Debris Model for Burial Grounds

\begin{tabular}{|c|c|c|}
\hline Site & Cross-Sectional Area $\left(\mathrm{m}^{2}\right)$ & Depth/Height (m) \\
\hline 100-B-3 & 999 & 5.3 \\
\hline 118-B-1 & 2,982 & 6.1 \\
\hline 118-B-2 & 167 & 3.0 \\
\hline 118-B-3 & 8,942 & 6.1 \\
\hline 118-B-4 & 139 & 4.6 \\
\hline 118-B-5 & 232 & 6.1 \\
\hline 118-B-6 & 13.9 & 6.1 \\
\hline 118-B-7 & 6.0 & 2.4 \\
\hline $118-\mathrm{C}-1$ & 18,952 & 6.1 \\
\hline $600-33$ & 37.2 & 5.3 \\
\hline $100-\mathrm{D}-3$ & 999 & 5.3 \\
\hline $100-\mathrm{D}-32$ & 231 & 5.3 \\
\hline $100-\mathrm{D}-40$ & 117 & 6.1 \\
\hline $100-\mathrm{D}-42$ & 277 & 5.3 \\
\hline $100-\mathrm{D}-43$ & 163 & 4.6 \\
\hline $100-\mathrm{D}-45$ & 181 & 5.2 \\
\hline $100-\mathrm{D}-47$ & 3,961 & 5.3 \\
\hline 118-D-1 & 15,677 & 6.1 \\
\hline $118-\mathrm{D}-2$ & 33,445 & 6.1 \\
\hline 118-D-3 & 23,226 & 6.1 \\
\hline $118-\mathrm{D}-4$ & 11,148 & 5.3 \\
\hline 118-D-5 & 149 & 3.0 \\
\hline 118-DR-1 & 871 & 5.3 \\
\hline 118-F-1 & 2,787 & 6.1 \\
\hline $118-\mathrm{F}-2$ & 11,148 & 6.1 \\
\hline $118-\mathrm{F}-3$ & 813 & 4.6 \\
\hline $118-F-5$ & 6,968 & 4.6 \\
\hline 118-F-6 & 7,432 & 5.5 \\
\hline $132-F-5$ & 223 & 5.3 \\
\hline 100-H-5 & 1,585 & 4.6 \\
\hline 118-H-1 & 24,387 & 6.1 \\
\hline 118-H-2 & 650 & 5.3 \\
\hline 118-H-3 & 8,210 & 6.1 \\
\hline $118-\mathrm{H}-4$ & 418 & 3.0 \\
\hline 118-H-5 & 5.6 & 3.0 \\
\hline $100-\mathrm{K}-2$ & 975 & 4.6 \\
\hline $118-\mathrm{K}-1$ & 66,890 & 6.1 \\
\hline $218-C-9$ & 16,983 & 5.3 \\
\hline 218-E-1 & 7,441 & 5.3 \\
\hline 218-E-RCRA & 44,792 & 12.2 \\
\hline 218-E-LLW & 44,792 & 12.2 \\
\hline
\end{tabular}


Table 5.1. (contd)

\begin{tabular}{|c|c|c|}
\hline Site & Cross-Sectional Area $\left(\mathrm{m}^{2}\right)$ & Depth/Height (m) \\
\hline U.S. Ecology & 409,300 & 5.3 \\
\hline 218-E-10 & 442,102 & 5.4 \\
\hline 218-E-12A & 4,415 & 5.4 \\
\hline 218-E-12B & 878,649 & 5.4 \\
\hline 218-E-2 & 22,165 & 5.4 \\
\hline 218-E-2A & 1,368 & 5.4 \\
\hline $218-E-4$ & 14,493 & 5.4 \\
\hline 218-E-5 & 6,433 & 5.4 \\
\hline 218-E-5A & 1,115 & 5.4 \\
\hline 218-E-7 & 27 & 5.4 \\
\hline 218-E-8 & 4,274 & 5.4 \\
\hline 218-E-9 & 3,967 & 5.4 \\
\hline $218-W-4 C$ & 231,886 & 5.3 \\
\hline $218-W-1$ & 22,168 & 5.3 \\
\hline $218-W-11$ & 9,290 & 4.6 \\
\hline $218-W-1 \mathrm{~A}$ & 25,686 & 5.3 \\
\hline $218-\mathrm{W}-2$ & 28,509 & 5.3 \\
\hline $218-\mathrm{W}-2 \mathrm{~A}$ & 182,214 & 5.3 \\
\hline $218-W-3$ & 33,924 & 5.3 \\
\hline $218-W-3 A$ & 211,677 & 5.3 \\
\hline 218-W-3AE & 226,500 & 5.3 \\
\hline $218-\mathrm{W}-4 \mathrm{~A}$ & 73,496 & 5.3 \\
\hline 218-W-4B & 29,952 & 5.3 \\
\hline $218-W-5$ & 364,626 & 5.3 \\
\hline $618-1$ & 3,300 & 5.3 \\
\hline $618-13$ & 581 & 4.6 \\
\hline $618-2$ & 6,991 & 5.3 \\
\hline $618-3$ & 6,243 & 4.6 \\
\hline $618-4$ & 12,173 & 5.3 \\
\hline $618-5$ & 5,376 & 5.3 \\
\hline $618-7$ & 43,737 & 5.3 \\
\hline $618-8$ & 5,574 & 5.3 \\
\hline $618-9$ & 687 & 0.999 \\
\hline $618-10$ & 23,226 & 5.3 \\
\hline $618-11$ & 34,839 & 5.3 \\
\hline 600-148-west (ERDF) & 648,000 & 20 \\
\hline 600-148-east (ERDF) & 648,000 & 20 \\
\hline \multicolumn{3}{|c|}{$\begin{array}{l}\text { ERDF }=\text { Environmental Restoration Disposal Facilit } \\
\text { HLW }=\text { High-level waste. } \\
\text { ILAW }=\text { Immobilized low-activity waste. } \\
\text { LLW }=\text { Low-level waste. } \\
\text { RCRA }=\text { Resource Conservation and Recovery Act. }\end{array}$} \\
\hline
\end{tabular}


Table 5.2. Summary of Site Depth/Height and Cross-Sectional Areas for Application in the Soil-Debris Model

\begin{tabular}{|c|c|c|c|c|c|}
\hline Site & Diameter (m) & Length (m) & Width (m) & Depth/Height (m) & $\begin{array}{c}\text { Cross-Sectional } \\
\text { Area }\left(\mathrm{m}^{2}\right)\end{array}$ \\
\hline $100-\mathrm{K}-42$ (Storage) & & 41.5 & 21.3 & 6.7 & 884 \\
\hline 100-K-43 (Storage) & & 41.5 & 21.3 & 6.7 & 884 \\
\hline 100-F-36 (Laboratory) & & 45.9 & 9.8 & 17.7 & 447 \\
\hline 100-F-38 (UPR) & & & & 0.999 & 0.999 \\
\hline 100-H-31 (UPR) & & & & 0.999 & 0.999 \\
\hline 100-K-78 (UPR) & & 19.4 & 16.4 & 0.999 & 318 \\
\hline 100-N-66 (Reactor-Soil) & & & & 0.999 & 19,526 \\
\hline 116-D-8 (Storage) & & & & 0.999 & 0.999 \\
\hline 116-KE-5 & & & & 3.9 & 99.9 \\
\hline 118-B-8 (Reactor-Soil) & & & & 0.999 & 3,948 \\
\hline 118-B-9 (Storage) & & 7.3 & 3.7 & 9.1 & 26.8 \\
\hline 118-C-3 (Reactor-Soil) & & & & 0.999 & 6,039 \\
\hline 118-C-4 (Storage) & & 12.2 & 7.6 & 5.3 & 92.9 \\
\hline 118-D-6 (Reactor-Soil) & & & & 0.999 & 3,948 \\
\hline 118-DR-2 (Reactor-Soil) & & & & 0.999 & 3,948 \\
\hline 118-F-4 (Crib) & & 3.0 & 3.0 & 4.6 & 9.3 \\
\hline 118-F-7 (Storage) & & 4.9 & 2.4 & 2.4 & 11.9 \\
\hline 118-F-8 (Reactor-Soil) & & & & 0.999 & 4,113 \\
\hline 118-H-6 (Reactor-Soil) & & & & 0.999 & 5,760 \\
\hline 118-KE-1 (Reactor-Soil) & & & & 0.999 & 5,344 \\
\hline 118-KE-2 (Storage) ${ }^{(\mathrm{a})}$ & & 12.2 & 7.6 & 9.1 & 92.9 \\
\hline 118-KW-1 (Reactor-Soil) & & & & 0.999 & 4,568 \\
\hline $118-\mathrm{KW}-2$ (Storage) $^{(\mathrm{a})}$ & & 12.2 & 7.6 & 9.1 & 92.9 \\
\hline $\begin{array}{l}\text { 120-D-2 (Surface } \\
\text { Impoundment) }\end{array}$ & & 28.1 & 28.1 & 4.3 & 792 \\
\hline 132-DR-2 (Stack) & 5.1 & & & 60.1 & 20.4 \\
\hline 141-C (Laboratory $)^{(\mathrm{b})}$ & & & & 18.2 & 431 \\
\hline $200-\mathrm{W}-40$ (Laboratory) $^{(\mathrm{c})}$ & & 15.2 & 7.0 & 20.4 & 107 \\
\hline 200-W-43 (Sand Filter) & & 26 & 26 & 4 & 676 \\
\hline 200-W-44 (Sand Filter) & & 29.3 & 29.3 & 6.7 & 856 \\
\hline 200-W-45 (Sand Filter) & & 33.6 & 15.2 & 4.9 & 511 \\
\hline 200-W-69 (Laboratory) ${ }^{(\mathrm{b})}$ & & 99.9 & 48.7 & 18.2 & 4,866 \\
\hline 200-E-30 (Sand Filter) & & 33.5 & 15.2 & 4.9 & 511 \\
\hline 200-E-103 (UPR) & & & & 0.999 & 17,326 \\
\hline 200-E-107 (UPR) & & 115 & 34.8 & 0.999 & 3,982 \\
\hline 200-E-115 (UPR) & & 9.1 & 9.1 & 0.999 & 83.5 \\
\hline 200-E-124 (UPR) & & 64 & 4.6 & 0.999 & 294 \\
\hline 200-E-125 (UPR) & & 6.8 & 4.4 & 0.999 & 30.3 \\
\hline 200-E-41 (UPR) & & 150 & 150 & 0.999 & 22,500 \\
\hline 200-E-44 (UPR) & & & & 0.999 & 9.99 \\
\hline 200-E-117 (UPR) & & 3.1 & 3.1 & 0.999 & 9.3 \\
\hline 200-E-121 (UPR) & & 200 & 24.4 & 0.999 & 4,876 \\
\hline 200-E-122 (Storage) ${ }^{(\mathrm{d})}$ & & 44 & 20 & 6.7 & 880 \\
\hline
\end{tabular}


Table 5.2. (contd)

\begin{tabular}{|c|c|c|c|c|c|}
\hline Site & Diameter $(\mathrm{m})$ & Length (m) & Width (m) & Depth/Height (m) & $\begin{array}{l}\text { Cross-Sectional } \\
\text { Area }\left(\mathrm{m}^{2}\right)\end{array}$ \\
\hline 200-E-123 (UPR) & & 7.1 & 4.5 & 0.999 & 32.0 \\
\hline $200-\mathrm{E}-128$ & & & & 0.999 & 0.018 \\
\hline 200-E-129 (UPR) & & 6.1 & 3.7 & 0.999 & 22.3 \\
\hline 200-E-130 (UPR) & & & & 0.999 & 0.999 \\
\hline 200-E-137 (Stack) & 4.3 & & & 61 & 14.5 \\
\hline 200-W-104 (Storage) & & & & 0.999 & 0.999 \\
\hline 200-W-15 (UPR) & & 12.2 & 2.4 & 0.999 & 29.7 \\
\hline 200-W-67 (UPR) & & 100 & 18 & 0.999 & 1,800 \\
\hline 200-W-76 (Storage) & & & & 0.999 & 9.99 \\
\hline 200-W-83 (UPR) & & 18.3 & 7.6 & 0.999 & 139 \\
\hline 200-W-85 (UPR) & & 6.1 & 6.1 & 0.999 & 37.2 \\
\hline 200-W-86 (UPR) & & 3.0 & 3.0 & 0.999 & 9.3 \\
\hline 200-W-87 (UPR) & & 36.6 & 9.1 & 0.999 & 334 \\
\hline 200-W-90 (UPR) & & & & 0.999 & 18.6 \\
\hline 202-A-WS-1 (Storage) & & & & 0.999 & 9.99 \\
\hline $212-\mathrm{N}(\text { Storage })^{(\mathrm{a})}$ & & & & 9.1 & 555 \\
\hline 212-P (Storage) ${ }^{(\mathrm{a})}$ & & & & 9.1 & 555 \\
\hline 212-R (Storage) ${ }^{(\mathrm{a})}$ & & & & 9.1 & 555 \\
\hline 216-Z-1A (Tile Field) & & 84 & 35 & 67 & 2,940 \\
\hline 216-Z-9 (Trench) & & 36.6 & 27.4 & 67 & 1,003 \\
\hline 216-Z-18 (Crib) & & 63.1 & 3.0 & 67 & 192 \\
\hline 218-E-14 (Storage Tunnel) & & 109 & 5.8 & 5.3 & 632 \\
\hline 218-E-15 (Storage Tunnel) & & 515 & 10.4 & 5.3 & 5,332 \\
\hline 221-B-WS-2 (Storage) & & 5.4 & 4.0 & 22.6 & 21.4 \\
\hline 222-SD (Storage) & & 5.8 & 4.9 & 2.6 & 27.8 \\
\hline 296-A-13 & & & & 13 & 18.5 \\
\hline 300-16 (UPR) & & & & 0.999 & 0.999 \\
\hline 300-24 (UPR) & & & & 0.999 & 2,572 \\
\hline 300-25 (Laboratory) & & 71.5 & 61.9 & 13.7 & 4,423 \\
\hline 300-251 (UPR) & & 30 & 25 & 0.999 & 450 \\
\hline $300-264$ (Laboratory) $^{(\mathrm{e})}$ & & 70 & 40 & 22.6 & 2,800 \\
\hline 300-28 (UPR) & & 168 & 6.5 & 0.999 & 1,055 \\
\hline 300-33 (UPR) & & 116 & 48.8 & 0.999 & 5,649 \\
\hline 300-39 (Storage) & & 27.4 & 10.1 & 0.999 & 276 \\
\hline $300-4$ (UPR) & & 19.5 & 21.3 & 0.999 & 415 \\
\hline 303-K_CWS (Storage) & & 24.1 & 28.7 & 4.1 & 690 \\
\hline 303-M-SA (Storage) & & 13.7 & 10.6 & 0.13 & 145 \\
\hline 305-B-SF (Storage) & & 36.9 & 11.6 & 5.5 & 427 \\
\hline 313-ESSP (Storage) & & & & 0.999 & 99.9 \\
\hline $4843{\text { (Storage })^{(\mathrm{f})}}$ & & 12.2 & 12.2 & 5.0 & 149 \\
\hline 600-108 (Storage) & & 12.2 & 3.7 & 2.4 & 44.6 \\
\hline $600-259$ (Laboratory) $^{(\mathrm{e})}$ & & 25 & 25 & 22.6 & 625 \\
\hline $600-59{\text { (Storage })^{(\mathrm{g})}}^{2}$ & & 6.1 & 4.6 & 2.6 & 27.9 \\
\hline RMWSF (Storage) ${ }^{(\mathrm{h})}$ & & & & 0.326 & 56,345 \\
\hline TRUSAF (Storage) $^{(\mathrm{d})}$ & & 60 & 18.3 & 6.7 & 1,098 \\
\hline
\end{tabular}


Table 5.2. (contd)

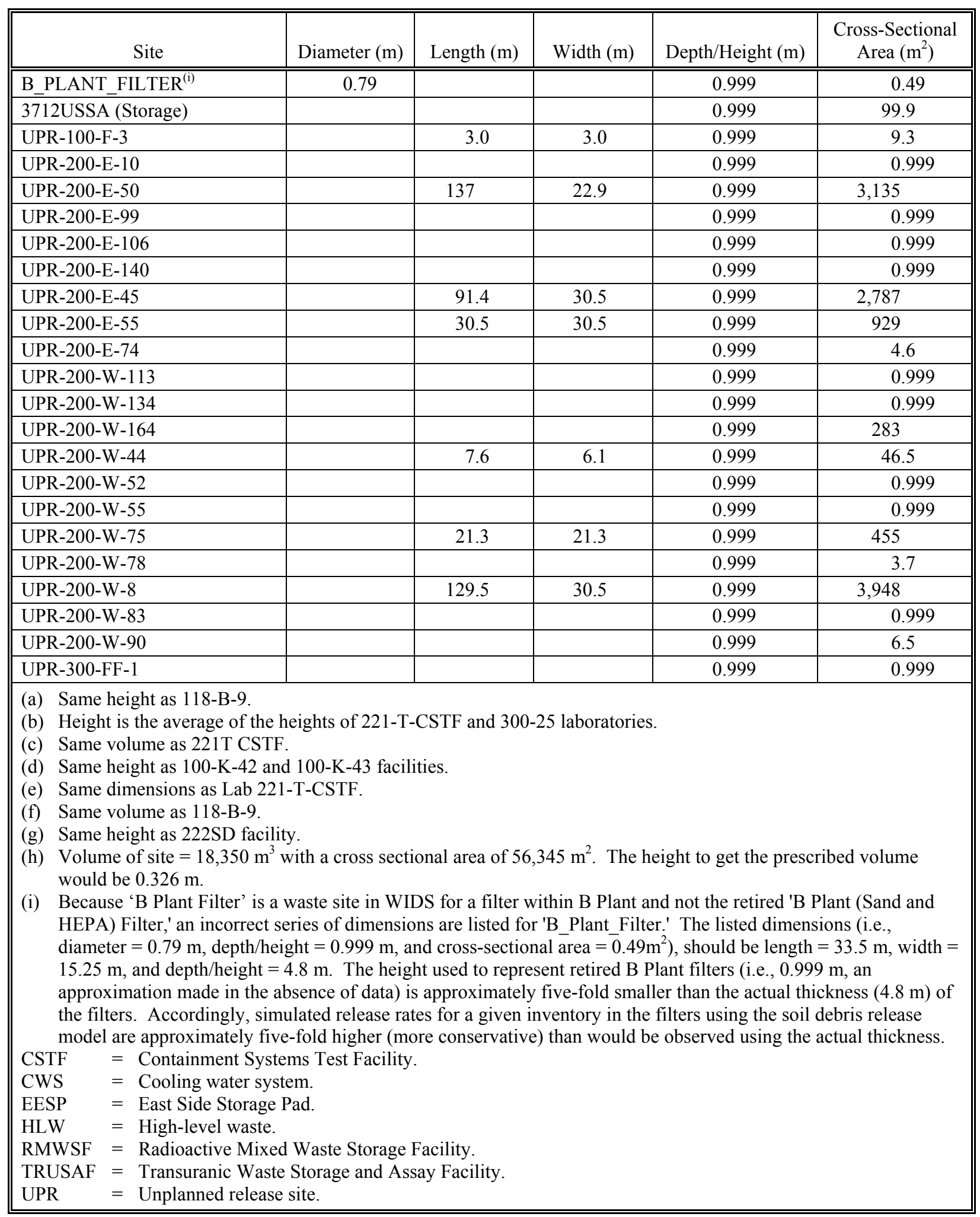


Table 5.3. Calculated Values ${ }^{(a)}$ of Bulk Density and Volumetric Moisture Content for Application in the Soil-Debris Model

\begin{tabular}{||l|c|c|}
\hline \multicolumn{1}{|c|}{ Area } & Bulk Density $\left(\mathrm{g} / \mathrm{cm}^{3}\right)$ & Volumetric Moisture Content $\left(\theta_{\mathrm{w}}\right)$ \\
\hline \hline $100^{(\mathrm{b})}$ & $2.16 \pm 0.20$ & $0.0830 \pm 0.0497$ \\
\hline $200 \mathrm{West}^{(\mathrm{c})}$ & $1.535 \pm 0.1085$ & $0.0594 \pm 0.0310$ \\
\hline $200 \mathrm{East}^{(\mathrm{d})}$ & $1.535 \pm 0.1085$ & $0.0594 \pm 0.0310$ \\
\hline $300^{(\mathrm{e})}$ & $2.16 \pm 0.20$ & $0.0657 \pm 0.0174$ \\
\hline
\end{tabular}

(a) Values are based on a statistical treatment of individual data points measured or calculated over a depth range from 0 to $6 \mathrm{~m}$.

(b) Bulk density and volumetric moisture content values calculated from bulk density and moisture content data from Peterson et al. (1996). Volumetric moisture content $(\theta)=$ volume of water in sample divided by ([dry weight of soil/bulk density] + volume of water).

(c) Bulk density and volumetric moisture content values for 200 East Area also used for the 200 West Area.

(d) Bulk density and volumetric moisture content values calculated from bulk density and moisture content data from Fayer et al. (1999).

(e) The same value of bulk density used in the 100 Area was assigned to the 300 Area. The volumetric moisture content value for the 300 Area was calculated from using the moisture content data found in Appendix B (page B.2) of Schalla et al. (1988).

Site recharge rates, site cross-sectional areas, and sorption factors are the same as those used by the vadose zone module (see the vadose zone data package for Hanford assessments, Last et al. 2006). Recharge rates vary based on current or predicted site conditions (e.g., soil type, presence or absence of vegetation or a cover) (Last 2006) and the precipitation record of the Hanford Site. In the case of the partition coefficient $\left(\mathrm{K}_{\mathrm{d}}\right)$ values, the soil-debris model uses values recently assigned as a result of an assessment of contaminant transport in Hanford sediments (Cantrell et al. 2002; Last et al. 2006). The most commonly used $\mathrm{K}_{\mathrm{d}}$ category (category 4 ) is that associated with sites that are low organic, low salts, and near neutral pH in chemistry (Table 5.4). Exceptions are six unplanned release sites (UPR-200-E-19, UPR-200-E-99, UPR-200-E-45, UPR-200-W-51, UPR-200-W-52, UPR-200-W-75) where a category 2 high-impact $\mathrm{K}_{\mathrm{d}}$ is used (Table 5.5).

Values of aqueous solubility $\left(\mathrm{C}_{\text {sol }}\right)$ for analytes were derived from experimental measurements or estimated based on geochemical calculations (e.g., using the MINTEQA2 computer code). For radionuclides where no specific solubility values were available or estimated, the aqueous solubility has been fixed at an arbitrarily high default value $\left(1 \times 10^{10} \mathrm{mg} / \mathrm{L}\right)$ so that the soil-debris release model automatically selects algorithms for sorption $\left(\mathrm{K}_{\mathrm{d}}\right)$ control in these cases (Kincaid et al. 1998). Radionuclides that have been assigned default values are tritium, technetium, iodine, strontium, and cesium. Uranium and plutonium solubility were calculated starting from values of uranium and plutonium estimated in Hanford groundwater (Wood et al. 1995) (Table 5.6). The solid phases assumed to control dissolved uranium and plutonium for these calculations were $\mathrm{UO}_{2}(\mathrm{OH})_{2} \bullet \mathrm{H}_{2} \mathrm{O}$ and $\mathrm{PuO}_{2} \bullet \mathrm{H}_{2} \mathrm{O}$.

\subsection{Cement Model}

Table 5.7 summarizes area to volume ratios (A/V) for various waste sources for which contaminant release will be simulated using the cement model for a Hanford assessment. Where site dimensions are not available (i.e., for length, width or height), default values of $9.99 \mathrm{~m}$ and $0.999 \mathrm{~m}$ are applied for length and width and height, respectively. For each site, $\mathrm{A} / \mathrm{V}$ is assumed to be constant for all time periods during any given realization of the assessment run. 
Table 5.4. Waste Chemistry/Source Category 4: Low Organic/Low Salt/Near Neutral

\begin{tabular}{|c|c|c|c|}
\hline \multirow[b]{3}{*}{ Analyte } & \multicolumn{3}{|c|}{ High Impact (F1) } \\
\hline & \multicolumn{3}{|c|}{$\mathrm{K}_{\mathrm{d}}$ Estimate $(\mathrm{mL} / \mathrm{g})$} \\
\hline & Best & Min & Max \\
\hline \multicolumn{4}{|c|}{ Non-Adsorbing Radionuclides } \\
\hline Tritium & 0 & 0 & 0 \\
\hline Technetium-99 & 0 & 0 & 0.1 \\
\hline Chlorine-36 & 0 & 0 & 0 \\
\hline \multicolumn{4}{|c|}{ Moderately Adsorbing } \\
\hline Iodine-129 & 0.2 & 0 & 2 \\
\hline Uranium-238 & 0.8 & 0.2 & 4 \\
\hline Selenium-79 & 5 & 3 & 10 \\
\hline Neptunium-237 & 10 & 2 & 30 \\
\hline Carbon-14 & 0 & 0 & 100 \\
\hline \multicolumn{4}{|c|}{ Highly Adsorbing } \\
\hline Strontium-90 & 22 & 10 & 50 \\
\hline Cesium-137 & 2,000 & 200 & 10,000 \\
\hline Plutonium-239 & 600 & 200 & 2,000 \\
\hline Europium-152 & 200 & 10 & 1,000 \\
\hline
\end{tabular}

Table 5.5. Waste Chemistry/Source Category 2: Very High Salt/Very Basic

\begin{tabular}{|c|c|c|c|}
\hline \multirow[b]{3}{*}{ Analyte } & \multicolumn{3}{|c|}{ High Impact (D) } \\
\hline & \multicolumn{3}{|c|}{$\mathrm{K}_{\mathrm{d}}$ Estimate $(\mathrm{mL} / \mathrm{g})$} \\
\hline & Best & Min & Max \\
\hline \multicolumn{4}{|c|}{ Non-Adsorbing Radionuclides } \\
\hline Tritium & 0 & 0 & 0 \\
\hline Technetium-99 & 0 & 0 & 0.1 \\
\hline Chlorine-36 & 0 & 0 & 0 \\
\hline \multicolumn{4}{|c|}{ Moderately Adsorbing } \\
\hline Iodine-129 & 0.02 & 0 & 0.2 \\
\hline Uranium-238 & 0.8 & 0.2 & 4 \\
\hline Selenium-79 & 0 & 0 & 0.1 \\
\hline Neptunium-237 & 200 & 100 & 500 \\
\hline Carbon-14 & 0 & 0 & 100 \\
\hline \multicolumn{4}{|c|}{ Highly Adsorbing } \\
\hline Strontium-90 & 22 & 10 & 50 \\
\hline Cesium-137 & 10 & 0 & 500 \\
\hline Plutonium-239 & 200 & 70 & 600 \\
\hline Europium-152 & 200 & 10 & 1,000 \\
\hline
\end{tabular}


Table 5.6. Analyte Aqueous Solubility Values and Interconversions

\begin{tabular}{||l|c|c|c|c|}
\hline \multicolumn{1}{|c|}{ Contaminant $^{(\mathrm{a})}$} & $\begin{array}{c}\text { Solubility } \\
(\mathrm{mg} / \mathrm{L})^{(\mathrm{b})}\end{array}$ & Solubility $\left(\mathrm{g} / \mathrm{cm}^{3}\right)$ & $\begin{array}{c}\text { Specific Activity } \\
(\mathrm{Ci} / \mathrm{g})^{(\mathrm{c})}\end{array}$ & $\begin{array}{c}\text { Solubility } \\
\left(\mathrm{Ci} / \mathrm{cm}^{3}\right)^{(\mathrm{d})}\end{array}$ \\
\hline \hline Tritium & $1 \times 10^{10}$ & $1 \times 10^{4}$ & $9.70 \times 10^{3}$ & $9.7 \times 10^{7}$ \\
\hline Carbon-14 & $1 \times 10^{10}$ & $1 \times 10^{4}$ & 4.47 & $4.47 \times 10^{4}$ \\
\hline Chlorine-36 & $1 \times 10^{10}$ & $1 \times 10^{4}$ & $3.30 \times 10^{-2}$ & $3.30 \times 10^{2}$ \\
\hline Selenium-79 & $1 \times 10^{10}$ & $1 \times 10^{4}$ & $6.98 \times 10^{-2}$ & $6.98 \times 10^{2}$ \\
\hline Strontium-90 & $1 \times 10^{10}$ & $1 \times 10^{4}$ & $1.37 \times 10^{2}$ & $1.37 \times 10^{6}$ \\
\hline Technetium-99 & $1 \times 10^{10}$ & $1 \times 10^{4}$ & $1.70 \times 10^{-2}$ & $1.7 \times 10^{2}$ \\
\hline Iodine-129 & $1 \times 10^{10}$ & $1 \times 10^{4}$ & $1.77 \times 10^{-4}$ & 1.77 \\
\hline Cesium-137 & $1 \times 10^{10}$ & $1 \times 10^{4}$ & $8.67 \times 10^{1}$ & $8.67 \times 10^{5}$ \\
\hline Europium-152 & $1 \times 10^{10}$ & $1 \times 10^{4}$ & $1.77 \times 10^{2}$ & $1.77 \times 10^{6}$ \\
\hline Radium-226 & $1 \times 10^{10}$ & $1 \times 10^{4}$ & $9.90 \times 10^{-1}$ & $9.90 \times 10^{3}$ \\
\hline Protactinium-231 & $1 \times 10^{10}$ & $1 \times 10^{4}$ & $4.71 \times 10^{-2}$ & $4.71 \times 10^{2}$ \\
\hline Uranium-233 & $86.9^{(\mathrm{e})}$ & $8.69 \times 10^{-5}$ & $9.69 \times 10^{-3}$ & $8.42 \times 10^{-7}$ \\
\hline Uranium-234 & $86.9^{(\mathrm{e})}$ & $8.69 \times 10^{-5}$ & $6.25 \times 10^{-3}$ & $5.47 \times 10^{-7}$ \\
\hline Uranium-235 & $86.9^{(\mathrm{e})}$ & $8.69 \times 10^{-5}$ & $2.16 \times 10^{-6}$ & $1.88 \times 10^{-10}$ \\
\hline Neptunium-237 & $8.1^{(\mathrm{e})}$ & $8.1 \times 10^{-6}$ & $7.05 \times 10^{-4}$ & $5.71 \times 10^{-9}$ \\
\hline Uranium-238 & $86.9^{(\mathrm{e})}$ & $8.69 \times 10^{-5}$ & $3.37 \times 10^{-7}$ & $2.95 \times 10^{-11}$ \\
\hline
\end{tabular}

(a) Listed contaminants are from Kincaid et al. (2004).

(b) For those contaminants, for which no specific aqueous solubility values were available, the aqueous solubility was fixed at an arbitrarily high default value $\left(1 \times 10^{10} \mathrm{mg} / \mathrm{L}\right)$ so that the soil debris model would automatically select algorithms for sorption control rather than solubility control in these cases (Kincaid et al. 1998).

(c) Values of specific activity are from Kincaid et al. (1998), Table D.2.

(d) Values to be used in soil-debris model for Hanford assessments.

(e) Uranium and neptunium solubility in Hanford groundwater were based on data from Appendix E of Wood et al. (1995). 
Table 5.7. Summary of Waste Source A/V Ratios for Sources Requiring Cement Release Model for Hanford Assessment Runs

\begin{tabular}{|c|c|c|c|c|c|c|}
\hline Waste Source & Length $(\mathrm{m})$ & Width (m) & Height (m) & Volume $\left(\mathrm{m}^{3}\right)$ & $\begin{array}{c}\text { Surface Area } \\
\left(\mathrm{m}^{2}\right)\end{array}$ & $\mathrm{A} / \mathrm{V}\left(\mathrm{m}^{-1}\right)$ \\
\hline $\begin{array}{l}\text { 100-D-53 (Process Unit/ } \\
\text { Plant) }\end{array}$ & 20.7 & 11.9 & 2.44 & 601 & 652 & 1.08 \\
\hline $100-\mathrm{K}-6$ & 2.7 & 2.7 & 0.999 & 7.28 & 25.37 & 3.48 \\
\hline $100-K-61^{(a)}$ & 9.99 & 9.99 & 2.44 & 240 & 296 & 1.23 \\
\hline $100-K-62^{(a)}$ & 9.99 & 9.99 & 2.44 & 240 & 296 & 1.23 \\
\hline $\begin{array}{l}\text { 116-KE-5 (Process } \\
\text { Unit/Plant) }^{\left({ }^{(a)}\right.}\end{array}$ & 9.99 & 9.99 & 2.44 & 243.51 & 297.10 & 1.22 \\
\hline $\begin{array}{l}\text { 116-KE-6D (Process Unit/ } \\
\text { Plant) }^{(a)}\end{array}$ & 9.99 & 9.99 & 2.44 & 240 & 296 & 1.23 \\
\hline $\begin{array}{l}\text { 116-KW-4 (Process Unit/ } \\
\text { Plant) }\end{array}$ & 9.99 & 9.99 & 2.44 & 240 & 296 & 1.23 \\
\hline $\begin{array}{l}\text { 200_ETF (Process } \\
\text { Unit/Plant) }^{(a)}\end{array}$ & 9.99 & 9.99 & 2.44 & 240 & 296 & 1.23 \\
\hline $\begin{array}{l}\text { 200-E-136 (Process } \\
\text { Unit/Plant-PUREX) }^{(\mathrm{b})}\end{array}$ & 12 & 20 & 10 & 2,400 & 1,120 & 0.47 \\
\hline 201-C (Process Unit/Plant) ${ }^{(\mathrm{c})}$ & 42.7 & 24.4 & 3 & 3,126 & 2,486 & 0.80 \\
\hline 202-S (Process Unit/Plant) ${ }^{(\mathrm{d})}$ & 12 & 20 & 10 & 2,400 & 1,120 & 0.47 \\
\hline $\begin{array}{l}\text { 203-S_\%_205-S (Process } \\
\text { Unit/Plant }^{(\mathrm{e})}\end{array}$ & & & & & & 1.8 \\
\hline 205A (Process Unit/Plant) & 3.7 & 3.0 & 2.4 & 26.6 & 54.4 & 2.05 \\
\hline 218-E-14 (Storage Tunnel) ${ }^{(\mathrm{f})}$ & 10 & 5 & 6 & 300 & 280 & 0.93 \\
\hline 218-E-15 (Storage Tunnel) ${ }^{(\mathrm{f})}$ & 10 & 5 & 6 & 300 & 280 & 0.93 \\
\hline 218-E-RCRA ${ }^{(\mathrm{g})}$ & 1.22 & 1.22 & 2.44 & 3.63 & 14.89 & 4.1 \\
\hline 218-E-LLW ${ }^{(g)}$ & 1.22 & 1.22 & 2.44 & 3.63 & 14.89 & 4.1 \\
\hline $\begin{array}{l}218-\mathrm{W}-3 \mathrm{AE} \text { (cement in } \\
\text { burial ground })^{(\mathrm{g})}\end{array}$ & 1.22 & 1.22 & 2.44 & 3.63 & 14.89 & 4.1 \\
\hline $\begin{array}{l}218-W-4 B \text { (cement waste in } \\
\text { burial ground })^{(\mathrm{g})}\end{array}$ & 1.22 & 1.22 & 2.44 & 3.63 & 14.89 & 4.1 \\
\hline $\begin{array}{l}218-\mathrm{W}-4 \mathrm{C} \text { (cement in curial } \\
\text { ground })^{(\mathrm{g})}\end{array}$ & 1.22 & 1.22 & 2.44 & 3.63 & 14.89 & 4.1 \\
\hline 221-B (Process Unit/Plant) ${ }^{(\mathrm{b})}$ & 12 & 20 & 10 & 2,400 & 1,120 & 0.47 \\
\hline 221-T (Process Unit/Plant) ${ }^{(\mathrm{b})}$ & 12 & 20 & 10 & 2,400 & 1,120 & 0.47 \\
\hline 221-U (Process Unit/Plant) ${ }^{(\mathrm{b})}$ & 12 & 20 & 10 & 2,400 & 1,120 & 0.47 \\
\hline 224-B (Process Unit/Plant) ${ }^{(\mathrm{h})}$ & 12 & 20 & 10 & 2,400 & 1,120 & 0.47 \\
\hline 224-T(Process Unit/Plant) ${ }^{(\mathrm{h})}$ & 12 & 20 & 10 & 2,400 & 1,120 & 0.47 \\
\hline 224-U (Process Unit/Plant) ${ }^{(\mathrm{h})}$ & 12 & 20 & 10 & 2,400 & 1,120 & 0.47 \\
\hline 225-B (Process Unit/Plant) ${ }^{(\mathrm{h})}$ & 12 & 20 & 10 & 2,400 & 1,120 & 0.47 \\
\hline
\end{tabular}


Table 5.7. (contd)

\begin{tabular}{|c|c|c|c|c|c|c|}
\hline Waste Source & Length (m) & Width (m) & Height (m) & Volume $\left(\mathrm{m}^{3}\right)$ & $\begin{array}{c}\text { Surface Area } \\
\left(\mathrm{m}^{2}\right)\end{array}$ & $\mathrm{A} / \mathrm{V}\left(\mathrm{m}^{-1}\right)$ \\
\hline 231-Z (Process Unit/Plant) ${ }^{(\mathrm{i})}$ & 66 & 66 & 1 & 4,356 & 8,976 & 2.06 \\
\hline 232-Z (Process Unit/Plant) ${ }^{(\mathrm{i})}$ & 17.4 & 11.3 & 1 & 197 & 451 & 2.29 \\
\hline 233-S (Process Unit/Plant) ${ }^{(\mathrm{i})}$ & 26.2 & 11.3 & 1 & 296 & 667 & 2.25 \\
\hline $\begin{array}{l}\text { 234-5Z (Process } \\
\text { Unit/Plant) }^{(\mathrm{i})}\end{array}$ & 195 & 34.6 & 1 & 6,747 & 13,593 & 2.01 \\
\hline 276-S (Process Unit/Plant) ${ }^{(\mathrm{i})}$ & 17.7 & 13.1 & 1 & 232 & 525 & 2.26 \\
\hline 276-U (Process Unit/Plant) & 20.2 & 16.5 & 2.4 & 800 & 842 & 1.05 \\
\hline 291-C (Process Unit/Plant) ${ }^{(a)}$ & 13.6 & 13.6 & 2.4 & 444 & 505 & 1.14 \\
\hline 291-U (Process Unit/Plant) & 5.8 & 5.5 & 4.3 & 137 & 160 & 1.17 \\
\hline 292-S (Process Unit/Plant) & 8.2 & 4.3 & 0.999 & 35.2 & 95.2 & 2.70 \\
\hline 293-S (Process Unit/Plant) & 8.8 & 4.9 & 0.999 & 43.1 & 114 & 2.65 \\
\hline $\begin{array}{l}300 \_ \text {VTS (Process } \\
\text { Unit/Plant) }^{(\mathrm{i})}\end{array}$ & 104 & 85.3 & 1 & 8,871 & 18,121 & 2.04 \\
\hline $\begin{array}{l}\text { 300-249 (Plant } \\
\text { Unit/Process) }^{\text {(a) }}\end{array}$ & 9.99 & 9.99 & 2.4 & 240 & 296 & 1.23 \\
\hline 303-M-UOF ${ }^{(a)}$ & 9.99 & 9.99 & 2.4 & 240 & 296 & 1.23 \\
\hline $\begin{array}{l}\text { 309-WS-1 (Process } \\
\text { Unit/Plant) }\end{array}$ & 4.3 & 4.3 & 4.9 & 90.6 & 120 & 1.32 \\
\hline $\begin{array}{l}\text { 309-WS-2 (Process } \\
\text { Unit/Plant) }\end{array}$ & 8.0 & 4.8 & 4.9 & 188 & 202 & 1.07 \\
\hline $\begin{array}{l}\text { 325-WTF (Process Unit/ } \\
\text { Plant) }\end{array}$ & 9.99 & 9.99 & 2.4 & 240 & 296 & 1.23 \\
\hline $\begin{array}{l}\text { 600-117 (Process } \\
\text { Unit/Plant) }{ }^{(\mathrm{i})}\end{array}$ & 143 & 91.4 & 1 & 13,070 & 26,609 & 2.04 \\
\hline $\begin{array}{l}\text { 600-148-east (Cement } \\
\text { Component in ERDF) }\end{array}$ & & & & 69.12 & 180.16 & 2.6 \\
\hline $\begin{array}{l}\text { 600-148-west (Cement } \\
\text { Component in ERDF) }\end{array}$ & & & & 69.12 & 180.16 & 2.6 \\
\hline $\begin{array}{l}\text { 618-11 (Cement Waste in } \\
\text { Burial Ground) }\end{array}$ & 3.0 & 2.5 & 7.6 & 57.0 & 98.6 & 1.73 \\
\hline WRAP (Process Unit/Plant) ${ }^{(\mathrm{i})}$ & 73.1 & 61.0 & 1 & 4,459 & 9,186 & 2.06 \\
\hline GTF (Process Unit/Plant) ${ }^{(\mathrm{a})}$ & 9.99 & 9.99 & 2.4 & 240 & 296 & 1.23 \\
\hline $\begin{array}{l}\text { GTFL (Cement Component } \\
\text { in Burial Ground) }\end{array}$ & 38.1 & 15.2 & 10.4 & 6,022 & 2,252 & 0.37 \\
\hline $\begin{array}{l}\text { HWVP (Process } \\
\text { Unit/Plant) }^{\text {(a) }}\end{array}$ & 9.99 & 9.99 & 2.4 & 240 & 296 & 1.23 \\
\hline 2711-S (Process Unit/Plant) & 4.2672 & 3.81 & 2.4384 & 39.64 & 71.91 & 1.81 \\
\hline
\end{tabular}


Table 5.7. (contd)

\begin{tabular}{||l|r|r|r|r|r|c||}
\hline \multicolumn{1}{|c|}{ Waste Source } & Length $(\mathrm{m})$ & Width $(\mathrm{m})$ & Height $(\mathrm{m})$ & Volume $\left(\mathrm{m}^{3}\right)$ & $\begin{array}{c}\text { Surface Area } \\
\left(\mathrm{m}^{2}\right)\end{array}$ & $\mathrm{A} / \mathrm{V}\left(\mathrm{m}^{-1}\right)$ \\
\hline \hline 2718-S (Process Unit/Plant) & 4.2672 & 3.81 & 2.4384 & 39.64 & 71.91 & 1.81 \\
\hline $\begin{array}{l}\text { 2904-SA (Process } \\
\text { Unit/Plant) }\end{array}$ & 2.4384 & 2.4384 & 2.1336 & 12.69 & 32.7 & 2.58 \\
\hline
\end{tabular}

(a) Same height as $276 \mathrm{U}$ facility.

(b) B, T, and U Plants (221 Buildings) are from the same construction plans. Each canyon is $247 \mathrm{~m}$ long, $24 \mathrm{~m}$ high, and $20 \mathrm{~m}$ wide; however, the canyon is divided into 20 sections, each $12 \mathrm{~m}$ long. The plan is to bring the canyons down to their cover blocks, and cover block to base thickness is $10 \mathrm{~m}$. Thus, the length is $12 \mathrm{~m}$, the height is $10 \mathrm{~m}$, and the width is $20 \mathrm{~m}$. The corresponding area is $1120 \mathrm{~m}^{2}$, volume is $2400 \mathrm{~m}^{3}$, and A/V is approximately $0.47 \mathrm{~m}^{-1}$.

(c) The hot-semi work building, the $\mathrm{C}$ Canyon has been brought down to the cover blocks and only $3 \mathrm{~m}$ of the facility - the below grade portion - remains. $\mathrm{A}=2486 \mathrm{~m}^{2}, \mathrm{~V}=3126 \mathrm{~m}^{3}$, and $\mathrm{A} / \mathrm{V}$ is approximately $0.8 \mathrm{~m}^{-1}$.

(d) The 202-S Building is another canyon structure, so the B Canyon A/V ratio is applied.

(e) The 203-S and 205-S facilities involve a large relatively thin concrete slab $84 \mathrm{~m}$ x $68 \mathrm{~m}$, and a below grade vault. Assuming the slab is $1-\mathrm{m}$ thick, the $\mathrm{A} / \mathrm{V}$ would be $\sim 2 \mathrm{~m}^{-1}$. Assuming the vault were the same as at $218-\mathrm{W}-7$, a cylinder $3.66 \mathrm{~m}$ diameter and $4.27 \mathrm{~m}$ high, the $\mathrm{A} / \mathrm{V}$ would be $1.56 \mathrm{~m}^{-1}$. Assuming the vault were the same as at $218-\mathrm{W}-8$, a box $3.05 \mathrm{~m} \mathrm{x}$ $3.05 \mathrm{~m} \times 3.66 \mathrm{~m}$, the $\mathrm{A} / \mathrm{V}$ would be $1.86 \mathrm{~m}^{-1}$. Use the mid-value of these three - an $\mathrm{A} / \mathrm{V}$ of $1.8 \mathrm{~m}^{-1}$.

(f) For the two PUREX tunnels, assume a concrete monolith formed by grout injection is the size of a rail car load; $10 \mathrm{~m}$ long $\mathrm{x}$ $6 \mathrm{~m}$ high $\times 5 \mathrm{~m}$ wide, $\mathrm{A}=280 \mathrm{~m}^{2}, \mathrm{~V}=300 \mathrm{~m}^{3}, \mathrm{~A} / \mathrm{V}$ is approximately $0.93 \mathrm{~m}^{-1}$.

(g) The A/V ratio for these sites is that used for grouted IDF waste (DOE 2005b).

(h) The below grade cells of the 224 Buildings are assumed to have the same release characteristics as the 221 or canyon buildings. Therefore, use the A/V ratio of approximately $0.47 \mathrm{~m}^{-1}$.

(i) For structures not containing below grade vaults, assume the D\&D effort will leave a buried 1-m thick concrete slab. Release from these sites (e.g., most buildings to be D\&D) will be from a planar slab from these sites (e.g., most buildings to be D\&D) will be from a planar slab with the area of the building footprint and thickness of $1 \mathrm{~m}$.

(j) In solid waste burial grounds, there are several waste packages used with cement or grout. They include 208-L drums with an $\mathrm{A} / \mathrm{V}$ ratio of $\sim 9 \mathrm{~m}^{-1}, 1.22 \times 1.22 \times 2.44 \mathrm{~m}$ macro-encapsulation boxes with an $\mathrm{A} / \mathrm{V}$ ratio of $4.1 \mathrm{~m}^{-1}$, concrete boxes $2.74 \mathrm{x}$ $3.96 \times 6.40 \mathrm{~m}$ with an A/V ratio of $1.5 \mathrm{~m}^{-1}$ is considered smooth walled and approximately $2.6 \mathrm{~m}^{-1}$ is considered wavy or "corrugated" in appearance. The 208-L drums are usually disposed in groups within the concrete boxes, thus, use of an A/V of $9 \mathrm{~m}^{-1}$ may be unreasonable. Use of the $1.5 \mathrm{~m}^{-1}$ value seems unreasonable too, because the concrete exterior walls are not smooth. This leads to the recommendation to use the $\mathrm{A} / \mathrm{V}$ value of $2.6 \mathrm{~m}^{-1}$ for concreted waste in this burial ground. This value is derived assuming cemented waste in ERDF to have vertical walls of a corrugated shape with a surface area $\left(180.16 \mathrm{~m}^{2}\right)$ roughly twice that of a cemented waste with smooth vertical walls $\left(107.36 \mathrm{~m}^{2}\right)$ and a volume of a concrete box $\left(69.12 \mathrm{~m}^{3}\right) . \mathrm{A} / \mathrm{V}=180.16 \mathrm{~m}^{2} / 69.12 \mathrm{~m}^{3}$ is approximately $2.6 \mathrm{~m}^{-1}$.

$\mathrm{A} / \mathrm{V}=$ Area to volume ratio.

D\&D $=$ Decontamination and decommissioning.

ERDF $=$ Environmental Restoration Disposal Facility.

ETF $=$ Effluent Treatment Facility.

GTF $=$ Grout Treatment Facility.

GTFL = Grout Treatment Facility Landfill.

HWVP = Hanford Waste Vitrification Plant.

IDF $\quad=$ Integrated Disposal Facility.

LLW $=$ Low-level waste.

PUREX = Plutonium-Uranium Extraction (Plant).

RCRA $=$ Resource Conservation and Recovery Act.

WRAP $=$ Waste Receiving and Processing Facility

WTF $\quad$ Waste Treatment Facility. 
contaminant release from solids remaining in a tank after sluicing. Alternatively, contaminant release from tank solid residuals will be simulated using the cement model for a Hanford assessment. Simulations may be conducted with the saltcake model as a sensitivity analysis in a Hanford assessment. Details on the historical application of the saltcake model to tank residuals can be found in Section 5.4 of Riley and Lo Presti (2004).

\subsection{Reactor Block Model}

The same model used to simulate release of radionuclides from decommissioned surplus production reactors in a previous site assessment will be used in a Hanford assessment (Kincaid et al. 1998). For a Hanford assessment, post-operational contaminant release from production reactor cores will occur beginning in 2065 following their burial on the Central Plateau. Radionuclide fractional release rates to be used in Hanford assessment release modeling are summarized in Table 5.9 (DOE 1989, p. C.3). With the exception of carbon-14, these release rates have been calculated from experimental leach rates (White et al. 1984) taking into account Hanford reactor configurations. The constant carbon-14 fractional release rate was calculated using a time dependent equation assuming a constant reactor temperature of $22^{\circ} \mathrm{C}$ for inclusion in Table 5.9 (DOE 1989, p. D.4). The fractional release rate for carbon-14 can be made time/temperature dependent. Details of this application can be found in Section 5.5 of Riley and Lo Presti (2004).

Table 5.9. Fractional Release Rates Available for Use in Reactor Block Model for a Hanford Assessment

\begin{tabular}{||l|c|}
\hline \multicolumn{1}{|c|}{ Analyte } & Fractional Release Rate $\left(\mathrm{y}^{-1}\right)$ \\
\hline \hline Carbon-14 & $6.9 \times 10^{-5}$ \\
\hline Cesium-137 & $1.10 \times 10^{-2}$ \\
\hline Chlorine-36 & $3.65 \times 10^{-4}$ \\
\hline Europium-152 & $2.92 \times 10^{-2}$ \\
\hline Iodine-129 & $3.65 \times 10^{-4}$ \\
\hline Neptunium-237 & $1.00 \times 10^{0}$ \\
\hline Selenium-79 & $2.92 \times 10^{-2}$ \\
\hline Strontium-90 & $1.10 \times 10^{-2}$ \\
\hline Technetium-99 & $2.92 \times 10^{-2}$ \\
\hline Tritium & $3.65 \times 10^{-4}$ \\
\hline Uranium 233/234/235/238 & $1.00 \times 10^{0}$ \\
\hline
\end{tabular}

(a) The fractional release rate for carbon-14 was calculated using the temperature dependent equation in Section 2.4.6 (365) $\left.\left[565\left(1+100 \mathrm{e}^{-0.08(365) 0.3}\right) \mathrm{e}^{-6440 / 295.15}\right]=6.9 \times 10^{-5} \mathrm{y}^{-1}\right)$ and assuming environmental impact statement conditions of steady-state release flux time ( $\mathrm{t}$ ) at steady-state flux conditions (at $0.3 \mathrm{yr}$ ) and constant temperature of $22^{\circ} \mathrm{C}\left(295.15^{\circ} \mathrm{K}\right)$ representative of conservative subsurface temperature at burial depths on the Central Plateau. The basis for the above assumptions was that it was noted that in using this equation for an assessment (Kincaid et al. 1998) that the release flux falls within $1 \%$ of its ultimate steady-state flux value at approximately 0.3 year. Compared to the length of simulations of a previous assessment (1,000 to 2,000 years) (Kincaid et al. 1998), the initial period of transient release was assumed to be insignificant. By assuming steady-state and constant temperature conditions, the above equation reduces to the form of the analytical solution used for the other radionuclides and a constant fractional release value rate for carbon-14 can be calculated.

(b) Fractional release rate for europium-154 used for europium-152 isotope. 


\subsection{Modeling Release from ILAW}

LAW glass as well as category 1 LLW, category 3 LLW, and mixed LLW in the IDF will be simulated in a Hanford assessment by importing the IDF performance assessment base case release-to-top of water-table file for all contaminants.

\subsection{Atmospheric Release Modeling}

For subsurface waste, VADER releases carbon-14 input from the Inventory Module to the Vadose Zone Module (STOMP) using the appropriate release model. STOMP partitions the VADER input into atmospheric and groundwater pathway components. STOMP assigns the amount of carbon-14 directed to the atmospheric pathway based on a carbon-14 to carbon dioxide rate as a function of temperature. For atmospheric release, the STOMP code requires data for distribution of the analyte between solid and liquid phases $\left(\mathrm{K}_{\mathrm{d}}\right)$, liquid and gas phases (Henry's law constant), and effective diffusion coefficients in the liquid and gas phases (Table 5.10). For a Hanford assessment, STOMP will assume upward migration by carbon-14 (as $\left.\mathrm{CO}_{2}\right)$ to occur in the gas phase only. The partition coefficient value for carbon-14 (as $\left.\mathrm{CO}_{2}\right)$ is assumed to be 0 . The Henry's law constants for carbon-14 $\left(\right.$ as $\left.\mathrm{CO}_{2}\right)$ and Iodine-129 (as $\left.\mathrm{I}_{2}\right)$ were calculated (Appendix D) based on data from an internet website database (Sanders 1999). A diffusion rate for small gaseous molecules moving through soil (Wood et al. 1995) was used for both carbon-14 (as $\mathrm{CO}_{2}$ ) and iodine- 129 .

Table 5.10. Parameter Values for Simulating Analyte Release from Buried Waste to the Atmosphere

\begin{tabular}{||l|c|c||}
\hline \multicolumn{1}{|c|}{ Coefficient } & Carbon-14 as $\mathrm{CO}_{2}$ & Iodine-129 as $\mathrm{I}_{2}$ \\
\hline \hline Distribution Coefficient $\left(\mathrm{K}_{\mathrm{d}}\right) \mathrm{mL} / \mathrm{g}$ & 0 & 0.2 \\
\hline Henry's Law Constant $\left(\mathrm{pa}-\mathrm{m}^{3} / \mathrm{mol}\right)^{(\mathrm{a})}$ & $3.918 \times 10^{3}$ & $5.609 \times 10^{1}$ \\
\hline Diffusion $\left(\mathrm{cm}^{2} / \mathrm{sec}\right)^{(\mathrm{b})}$ & 0.01 & 0.01 \\
\hline $\begin{array}{l}\text { (a) See Appendix D for calculations. } \\
\text { (b) Diffusion coefficient for low atomic number gases moving through soil (Wood et al. 1995). }\end{array}$ \\
\hline
\end{tabular}




\subsection{Parameter Uncertainties, Data Gaps, Technical Issues, and Recommendations}

The term uncertainty in modeling expresses known and unknown quantities and variability in inputs and predictions due to lack of knowledge. Sources of uncertainty in the Release Module include lack of precise knowledge about inventories, site characteristics, and physical and chemical processes relating to release rates.

For a Hanford assessment, data used for the various release model parameters will be assigned the statistical treatments listed in Table 6.1. The impact of these settings on results varies by waste type. For example, all the variability in reactor core release simulations comes from variability input to the reactor core inventory. The same is true for cement releases that are given constant diffusion coefficients. In all cases, the waste site dimensions (area, height, volume) will be treated as constants over all realizations. Infiltration rate time profiles will vary over realizations for the updated Hanford assessment. In particular, periods representing ground cover will be the same over all realization, but the infiltration rate for a given ground cover period will vary stochastically from realization to realization. Imparting more variability to infiltration rates might be expected to result in more accurate estimate of uncertainty in a Hanford assessment.

Table 6.1. Stochastic Treatment of Release Model Parameters Expected to be Implemented in a Hanford Assessment. In all cases, the waste site dimensions (cross-sectional area, height, volume, surface area) are treated as constants.

\begin{tabular}{|c|c|c|c|}
\hline Model & Variable Parameters & Fixed Parameters & Remarks \\
\hline Liquid & & Fractional release rate & Release rate set at 1 \\
\hline Soil-Debris & $\begin{array}{l}\text { Soil moisture content } \\
\text { Soil bulk density } \\
\text { Infiltration rate }\end{array}$ & $\begin{array}{l}\text { Solubility } \\
\mathrm{K}_{\mathrm{d}} \text { (desorption coefficient) }\end{array}$ & $\begin{array}{l}\text { Tritium } \\
\mathrm{K}_{\mathrm{d}} \text { set to } 0 \text { to express } \\
\text { maximum mobility }\end{array}$ \\
\hline Soil-Debris & $\begin{array}{l}\mathrm{K}_{\mathrm{d}} \text { (desorption coefficient) } \\
\text { Soil moisture content } \\
\text { Soil bulk density } \\
\text { Recharge rate }\end{array}$ & Solubility & $\begin{array}{l}\text { All analytes except } \\
\text { tritium }\end{array}$ \\
\hline Cement & & Diffusion coefficient & All analytes \\
\hline Reactor Core & & Fractional release & All analytes \\
\hline Saltcake & $\begin{array}{l}\rho \text { (saltcake density) } \\
\text { Recharge rate }\end{array}$ & Salt solubility & All analytes \\
\hline Glass $^{(a)}$ & Not applicable & Not applicable & Not applicable \\
\hline
\end{tabular}

(a) Low-activity waste (LAW) glass as well as category 1 low-level waste (LLW), category 3 LLW, and mixed LLW in the Integrated Disposal Facility (IDF) will be simulated in a Hanford assessment by importing the IDF performance assessment base case release-to-top of water-table file for all contaminants. 


\subsection{Consistency Discussion}

This data package is a refinement of an initial assessment release data package (Riley and Lo Presti 2004). Areas addressed in this data package that are absent in the data package associated with the SAC Initial Assessment include 1) an improved conceptualization of the structure of the Release Module of SAC, 2) a conceptual model of contaminant release from engineered waste systems, 3 ) an implementation model of contaminant release from engineered waste systems, 4) improved documentation of model parameter data sets, and 5) modeling analyte release to the atmospheric pathway from buried waste. 


\subsection{Conclusions and Recommendations}

This document contains the data package for the Release Module (VADER Revision 1) of SAC for conducting a Hanford assessment. The document includes a description of the Release Module and associated links to the other SAC modules, a conceptual model for contaminant release from engineered waste systems represented by the Release Module, an implementation model that describes key input parameters and outputs of the numerical models comprising the Release Module, and descriptions of the numerical models used to simulate contaminant release from specific waste sources. Sources of data for numerical model input parameters are described and the data to be used in a Hanford assessment are summarized in parameter specific tables. Parameter uncertainty is addressed in the context of the release models to be applied in the assessment.

Improvements have been made to the SAC Release Module capability since it was first used to conduct the SAC Initial Assessment (Bryce et al. 2002). Improvements include 1) numerical models that account for the effects of different types of waste containment (e.g., concrete containers and metal liners) and 2) the consideration of the atmospheric pathway for release of selected contaminants from buried waste. Of these new capabilities, modeling of contaminant release from buried waste to the atmosphere is to be implemented in a Hanford assessment.

The cement model, rather than the saltcake model, will be used to simulate contaminant release from tank high-level waste residuals in a Hanford assessment. This decision was made recognizing that residuals remaining after tank waste recovery likely have a composition similar to sludge and hard heel than saltcake. It is expected that this change will result in less conservative (slower release) but more realistic estimates of contaminant release from tank residuals than were observed in the results of the SAC Initial Assessment. This simulation approach is viewed as the best option at this time pending the development of new models for simulating contaminant release from tank residuals based on the results of ongoing Hanford research (Deutsch et al. 2005). The approach also allows for some basis of comparison with release modeling associated with ongoing tank farm closure assessments.

The extent of documentation of parameter data has improved with the publication of this data package. This includes the traceability of the data to the updated version of the release data catalog that provides a direct link to published sources of raw data. As a result, this report serves as a technical document that will support the findings of a Hanford assessment in a scientifically defensible fashion. 


\subsection{References}

40 CFR 258.40. 2003. “Criteria for Municipal Solid Waste Landfills; Design Criteria.” U.S. Environmental Protection Agency, U.S. Code of Federal Regulations.

Bacon DH, MD White, and BP McGrail. 2000. Subsurface Transport Over Reactive Multiphases (STORM): A General, Coupled, Nonisothermal Multiphase Flow, Reactive Transport, and Porous Medium Alteration Simulator, Version 2, User's Guide. PNNL-13108, Pacific Northwest National Laboratory, Richland, Washington.

Bonaparte R and BA Gross. 1990. "Field Behavior of Double-Liner Systems." In: Waste Containment Systems: Construction, Regulation and Performance, R Bonaparte (ed.), Geotechnical Publication 1.26, American Society of Chemical Engineering.

Bryce RW, CT Kincaid, PW Eslinger, and LF Morasch (eds.). 2002. An Initial Assessment of Hanford Impact Performed with the System Assessment Capability. PNNL-14027, Pacific Northwest National Laboratory, Richland, Washington.

Cantrell KJ, RJ Serne, and GV Last. 2002. Hanford Contaminant Distribution Coefficient Database and Users Guide. PNNL-13895, Pacific Northwest National Laboratory, Richland, Washington.

Chen G, TA Ferryman, KM Remund, SA Hartley, F Gao, CA Lo Presti, TJ DeForest, JG Hill, CA Weier, BG Amidan, and DK Gemeinhart. 1998. Methodology for Uncertainty Estimation of Hanford Tank Chemical and Radionuclide Inventories and Concentrations. PNNL-11842, Pacific Northwest National Laboratory, Richland, Washington.

Deutsch WJ, KM Krupka, KJ Cantrell, CF Brown, M Lindburg, HT Schaef, SM Heald, BW Arey, and RK Kukkadapu. 2005. Advances in Geochemical Testing of Key Contaminants in Residual Hanford Tank Waste. PNNL-15372, Pacific Northwest National Laboratory, Richland Washington.

DOE. 1989. Decommissioning of Eight Surplus Production Reactors at the Hanford Site, Richland, Washington. DOE/EIS-0119D, U.S. Department of Energy, Washington, D.C.

DOE. 1996. Tank Waste Remediation System, Hanford Site, Richland, Washington, Final Environmental Impact Statement. DOE/EIS-0189, Vol. 5, U.S. Department of Energy, Richland, Washington.

DOE. 2005. 2004 Annual Status Report for the Composite Analysis of Low-Level Waste Disposal in the Central Plateau at the Hanford Site. DOE/RL-2005-58, U.S. Department of Energy, Richland, Washington.

Duncan DR, DI Weyns-Rollosson, JA Pottmeyer, and TJ Stratton. 1995. A History of Solid Waste Packaging at the Hanford Site. WHC-SA-2772-FP, Westinghouse Hanford Company, Richland, Washington.

EPA. 1997. Geosynthetic Clay Liners Used in Municipal Solid Waste Landfills. EPA 530-F-97-002, U.S. Environmental Protection Agency, Washington, D.C. 
Escalante E. 1989. “Concepts of Underground Corrosion.” In: Effects of Soil Characteristics on Corrosion. V Chaker and J David Palmer (eds.), American Society for Testing and Materials, Philadelphia, Pennsylvania.

Eslinger PW, DW Engel, LH Gerhardstein, CA Lo Presti, TB Miley, WE Nichols, DL Strenge, and SK Wurstner. 2004. User Instructions for the Systems Assessment Capability, Rev. 1, Computer Codes, Volume 1: Inventory, Release, and Transport Modules. PNNL-14852, Vol. 1, Pacific Northwest National Laboratory, Richland, Washington.

Fayer MJ, EM Murphy, JL Downs, FO Kahn, CW Lindenmeier, and BN Bjornstad. 1999. Recharge Data Package for the Immobilized Low-Activity Waste 2001 Performance Assessment. PNNL-13033, Pacific Northwest National Laboratory, Richland, Washington.

Harbour JR, TB Edwards, TH Lorier, and CA Langton (Westinghouse Savannah River Company), RC Moore, JL Krumhansl, KC Holt, F Solas, and CA Sanchez (Sandia National Laboratory). 2004. Stabilizing Grout Compatibility Study. WSRC-TR-2004-00021, Rev. 0, Westinghouse Savannah River Company, Aiken, South Carolina.

Kincaid CT, JW Shade, GA Whyatt, MG Piepho, K Rhoads, JA Voogd, JH Westsik, Jr., MD Freshley, KA Blanchard, and BG Lauzon. 1995. Performance Assessment of Grouted Double-Shell Tank Waste Disposal at Hanford, Volume 1. WHC-SD-WMEE-004, Rev. 1, Westinghouse Hanford Company, Richland, Washington.

Kincaid CT, MP Bergeron, CR Cole, MD Freshley, NL Hassig, VG Johnson, DI Kaplan, RJ Serne, GP Streile, DL Strenge, PD Thorne, LW Vail, GA Whyatt, and SK Wurstner. 1998. Hanford Assessment for Low-Level Waste Disposal in the 200 Area Plateau of the Hanford Site. PNNL-11800, Pacific Northwest National Laboratory, Richland, Washington.

Kincaid CT, RW Bryce, and JW Buck. 2004. Technical Scope and Approach for the 2004 Composite Analysis of Low Level Waste Disposal at the Hanford Site. PNNL-14372, Pacific Northwest National Laboratory, Richland, Washington.

Last GV, WE Nichols, and CT Kincaid. 2004. Geographic and Operational Site Parameters List (GOSPL) for the 2004 Hanford assessment. PNNL-14725, Rev. 0, Pacific Northwest National Laboratory, Richland, Washington.

Last GV, EJ Freeman, KJ Cantrell, MJ Fayer, GW Gee, WE Nichols, BN Bjornstad and DG Horton. 2006. Vadose Zone Hydrogeology Data Package for Hanford Assessments. PNNL-14702, Rev. 1, Pacific Northwest National Laboratory, Richland, Washington.

McGrail BP, JG Darab, GJ Lumetta, SV Mattigod, and SL Wallen. 2001. Physicochemical Processes Controlling the Source Term from Tank Residuals. Proposal to the U.S. Department of Energy Office of Science and Office of Environmental Management FY 2001 Environmental Management Science Program Notice 01-16, Basic Science Research Related to High Level Radioactive Waste, U.S. Department of Energy, Washington, D.C.

Meyers DR and DA Duranceau. 1994. Prototype Hanford Surface Barrier: Design Basis Document. BHI-00007, Rev. 00, Bechtel Hanford, Inc., Richland, Washington. 
Napier BA. 2002. Recommendations Concerning the Atmospheric Transport Pathway for SAC Rev. 1. White Paper.

Napier BA and JV Ramsdell, Jr. 2005. Atmospheric Data Package for the Hanford Assessment. PNNL-14599, Rev. 1, Pacific Northwest National Laboratory, Richland, Washington.

Pihlajavaara S. 1994. Estimation of the Service Life of Concrete Under Different Environments. Life Prediction of Corrodible Structures. Volume 1. RN Parkins (ed.), NACE International, Houston, Texas.

Peterson RE, RF Raidl, and CW Denslow. 1996. Conceptual Site Model for Groundwater Contamination at 100 BC-5, 100 KR-4, 100 HR-3, and 100 FR-3 Operable Units. BHI-00917, Rev. 0, Bechtel Hanford, Inc., Richland, Washington.

Pierce EM, BP McGrail, EA Rodriquez, HT Schaef, P Saripalli, RJ Serne, KM Krupka, PF Martin, SR Baum, KN Geiszler, LR Reed, and WJ Shaw. 2004. Waste Form Release Data Package for the 2005 Integrated Disposal Facility Performance Assessment. PNNL-14805, Pacific Northwest National Laboratory, Richland, Washington.

Resource Conservation and Recovery Act. 1976. Public Law 94-580, as amended, 90 Stat. 2795, 42 USC 6901 et seq.

Riley RG and CA Lo Presti. 2001. Data Catalog for Models Simulating Release of Contaminants from Hanford Site Waste Sources. PNNL-13666, Rev. 0, Pacific Northwest National Laboratory, Richland, Washington.

Riley RG and CA Lo Presti. 2003. Data Catalog for Models Simulating Release of Contaminants from Hanford Site Waste Sources. PNNL-13666, Rev. 1, Pacific Northwest National Laboratory, Richland, Washington.

Riley RG and CA Lo Presti. 2004. Release Data Package for the 2004 Composite Analysis. PNNL-14760, Rev. 0, Pacific Northwest National Laboratory, Richland, Washington.

Sanders, R. 1999. Compilation of Henry's Law Constants for Inorganic and Organic Species of Potential Importance in Environmental Chemistry. http://www.mpch-mainz.mpg.de/ sander/res/henry.html.

Serne RJ and MI Wood. 1990. Hanford Waste-Form Release and Sediment Interaction: A Status Report with Rationale and Recommendations for Additional Studies. PNL-7297, Pacific Northwest Laboratory, Richland, Washington.

Serne RJ, RO Lokken, and LJ Criscenti. 1992. "Characterization of Grouted Low-Level Waste to Support Performance Assessment.” Waste Management 12:271-287.

Schalla R, RW Wallace, RL Aaberg, SP Airhart, DJ Bates, JVM Carlile, CS Cline, DI Dennison, MD Freshley, PR Heller, EJ Jensen, KB Olsen, RR Parkhurst, JT Rieger, and EJ Westergard. 1988. Interim Characterization Report for the 300 Area Process Trenches. PNL-6716, Pacific Northwest Laboratory, Richland, Washington. 
Streile GP, KD Shields, JL Stroh, LM Bagaasen, G Whelan, JP McDonald, JG Droppo, and JW Buck. 1996. The Multimedia Environmental Pollutant Assessment System (MEPAS): Source-Term Release Formulations. PNNL-11248, Pacific Northwest National Laboratory, Richland, Washington.

Walton JC, S Bib-Shafique, RW Smith, N Gutierrez, and A Tarquin. 1997. "Role of Carbonation in Transient Leaching of Cementitious Waste Forms.” Environmental Science and Technology 31:2345-2349.

White IF, GM Smith, LJ Saunders, CJ Kaye, TJ Martin, GH Clarke, and MW Wakerley. 1984. Assessment of Management Modes for Graphite from Reactor Decommissioning. EUR-9232, Commission of European Communities, Luxembourg.

Wood MI, R Kahleel, PD Rittmann, AH Lu, SH Finfrock, RJ Serne, KJ Cantrell, and TH DeLorenzo. 1995. Performance Assessment for the Disposal of Low-Level Waste in the 200 West Area Burial Grounds. WHC-EP-0645, Westinghouse Hanford Company, Richland, Washington.

Wood MI, R Kahleel, PD Rittmann, SH Finfrock, TH DeLorenzo, and DY Garbrick. 1996. Performance Assessment for the Disposal of Low-Level Waste in the 200 East Area Burial Grounds. WHC-SD-WMTI-730, Rev. 0, Westinghouse Hanford Company, Richland, Washington. 
Appendix A

Technical Justification for Exclusion of the Naval Reactor Compartments as Sources of Contaminant Release 


\section{Appendix A}

\section{Technical Justification for Exclusion of the Naval Reactor Compartments as Sources of Contaminant Release}

Since 1986, decommissioned Naval reactor compartments have been emplaced in trench 94 of solid waste burial ground 218-E-12B, located on the Central Plateau at DOE's Hanford Site in southeastern Washington State. Plans call for continued emplacement through 2020 when it is estimated that 220 reactor compartments will be located in the trench.

In a previous site assessment (Kincaid et al. 1988), radionuclide inventories associated with the emplaced reactor compartments were excluded from inventories associated with the 218-E-12B burial ground because they consist of activation products within corrosion-resistant metals (Kincaid et al. 1998, Appendix A, page A.6), and the analysis was for a relatively short 1,000-year post-closure period. The modeling capability to be applied in future assessments is more sophisticated and allows consideration of the impact of reactor compartment inventories as an independent source term, and analyses are now for a 10,000-year post-closure period. The new capability to examine individual sources or types of sources, and the longer time period of analysis require a re-evaluation of the Naval reactor compartments as a potential source term.

The long-lived radionuclide inventory is contained in the reactor vessel internal structure, housed within each reactor compartment (DOE 1996, Appendix D, p. D-6). Release of radionuclide inventories from the reactor compartments requires breaching of a minimum of approximately $0.152 \mathrm{~m}$ of steel containment (DOE 1996, Appendix B, p. B-4). The length of time before access to the internal structure can occur is governed by both the uncertainty in the rate of corrosion of the steel containment and soil pressure exerted on the exterior of the reactor compartment disposal package.

The Department of the Navy has estimated, based on calculations made using the maximum and expected corrosion rates and the minimum steel containment thickness (DOE 1996, Appendix B, Table B-2, p. B-9), and taking into account the effects of soil pressure (DOE 1996, Appendix B, p. B-8), that time until access to the internal structure of the reactor vessel is 10,000 to 30,000 years. Thus, the release of radionuclide inventories from the Naval reactor compartment source term will not occur during planned simulation time frame of future assessments, i.e., 10,000-years post-closure. Therefore, further consideration of inclusion of this source term in future assessments is deemed unnecessary.

\section{A.1 References}

DOE. 1996. Final Environmental Impact Statement on the Disposal of Decommissioned, Defueled Cruiser, Ohio Class, and Los Angeles Class Naval Reactor Plants. DOE/EIS-0259, United States Department of the Navy, Washington, D.C.

Kincaid CT, MP Bergeron, CR Cole, MD Freshly, NL Hassig, VG Johnson, DI Kaplan, RJ Serne, GP Streile, DL Strenge, PD Thorne, LW Vail, GA Whyatt, and SK Wurstner. 1998. Composite Analysis for Low-Level Waste Disposal in the 200 Area Plateau of the Hanford Site. PNNL-11800, Pacific Northwest National Laboratory, Richland, Washington. 


\section{Appendix B}

\section{Justification for Exclusion from Consideration of Chlorine-36}

as a Subsurface Source of Release to the Atmosphere 


\section{Appendix B}

\section{Justification for Exclusion from Consideration of Chlorine-36 as a Subsurface Source of Release to the Atmosphere}

The surplus production reactor environmental impact statement (EIS) states that "the major pathway for transport of radionuclides and chemicals to the effected environment is groundwater" (DOE 1989, Appendix G, page G.1). Of the radionuclides modeled, only carbon-14 is considered in the atmospheric pathway (DOE 1989, Appendix G, page G.27). While chlorine-36 is considered a constituent for assessment in the groundwater pathway (DOE 1989, Appendix C, page C.2; Appendix D, page D.4), no where in the draft EIS report (DOE 1989) or in its supplement (DOE 1992) is mention made of chlorine-36 as a source of atmospheric release. Release of chlorine-36 from surplus production reactors by way of the atmospheric pathway was not considered in the past composite analysis (Kincaid et al. 1998, page 4.33) or in other Hanford assessments where the atmospheric pathway is addressed (WDOE/WDOH 2000; DOE 1996a, 1996b, 2004; Jacobs 1996; Kincaid et al. 1995; Lockheed Martin Hanford, Inc. 1995; Mann et al. 2001; Wood et al. 1995a, 1995b, 1996). Therefore, it can be concluded from the above, and while not directly addressed, that chlorine-36 was not identified as an important atmospheric pathway constituent in assessment of radionuclide contaminant release from surplus production reactors or other waste disposed at Hanford.

\section{B.1 References}

WDOE/WDOH. 2000. Draft Environmental Impact Statement: Commercial Low-Level Radioactive Waste Disposal Site, Richland, Washington. Washington State Department of Ecology/Washington State Department of Health.

DOE. 1989. Decommissioning of Eight Surplus Production Reactors at the Hanford Site, Richland, Washington. DOE/EIS-0119D, U.S. Department of Energy, Richland, Washington.

DOE. 1992. Decommissioning of Eight Surplus Production Reactors at the Hanford Site, Richland, Washington: Addendum (Final Environmental Impact Statement). DOE/EIS-0119F, U.S. Department of Energy, Washington, D.C.

DOE. 1996a. Final Environmental Impact Statement on the Disposal of Decommissioned, Defueled Cruiser, Ohio Class, and Los Angeles Class Naval Reactor Plants. DOE/EIS-0259, U.S. Department of the Navy, Washington, D.C.

DOE. 1996b. Tank Waste Remediation System, Hanford Site, Richland, Washington, Final Environmental Impact Statement, Volume 5. DOE/EIS-0189, U.S. Department of Energy, Washington, D.C.

DOE. 2004. Final Hanford Site Solid (Radioactive and Hazardous) Waste Program Environmental Impact Statement Richland, Washington. DOE/EIS-0286F, U.S. Department of Energy, Richland, Washington. 
Jacobs. 1996. Engineering Calculations for the Tank Waste Remediation System Environmental Impact Statement. Jacobs Engineering Group, Inc., Kennewick, Washington.

Kincaid CT, JW Shade, GA Whyatt, MG Piepho, K Rhoads, JA Voogd, JH Westick, Jr., MD Freshley, KA Blanchard, and BG Lauzon. 1995. Volume 1: Performance Assessment of Grouted Double-Shell Tank Waste Disposal at Hanford. WHC-SD-WM-EE-004, Rev. 1, Westinghouse Hanford Company, Richland, Washington.

Kincaid CT, MP Bergeron, CR Cole, MD Freshley, NL Hassig, VG Johnson, DI Kaplan, RJ Serne, GP Streile, DL Strenge, PD Thorne, LW Vail, GA Whyatt, and SK Wurstner. 1998. Composite Analysis for Low-Level Waste Disposal in the 200 Area Plateau of the Hanford Site. PNNL-11800, Pacific Northwest National Laboratory, Richland, Washington.

Lockheed Martin Hanford Corporation. 1995. Supplemental Information Provided to the Peer Review Panel During Final Review of the 200 West Area Performance Assessment Analysis. HNF-SD-WMTI-798, Rev. 0, Lockheed Martin Hanford Corporation, Richland, Washington.

Mann FM, KC Burgard, WR Root, RJ Puigh, SH Finfrock, R Khaleel, DH Bacon, EJ Freeman, BP McGrail, and SK Wurstner. 2001. Hanford Immobilized Low-Activity Waste Performance Assessment: 2001 Version. DOE/ORP-2000-24, Rev. 0, U.S. Department of Energy, Richland, Washington.

Wood MI, R Khaleel, PD Rittmann, AH Lu, SH Finfrock, RJ Serne, KJ Cantrell, and TH DeLorenzo. 1995a. Performance Assessment for the Disposal of Low-Level Waste in the 200 West Area Burial Grounds. WHC-EP-0645, Westinghouse Hanford Company, Richland, Washington.

Wood MI, R Khaleel, PD Rittmann, AH Lu, SH Finfrock, and TH DeLorenzo. 1995b. Environmental Restoration Disposal Facility Performance Assessment. BHI-00169, Rev 00, Bechtel Hanford, Inc., Richland, Washington.

Wood MI, R Khaleel, PD Rittmann, SH Finfrock, TH DeLorenzo, and DY Garbrick. 1996. Performance Assessment for the Disposal of Low Level Waste in the 200 East Area Burial Grounds. WHC-SD-WMTI-730, Rev. 0, Westinghouse Hanford Company, Richland, Washington. 


\section{Appendix C}

Justification for Exclusion of Consideration of Iodine-129 (as $\mathbf{I}_{2}$ ) as a Subsurface Source of Release to the Atmosphere 


\section{Appendix C}

\section{Justification for Exclusion of Consideration of Iodine-129 (as $\mathbf{I}_{2}$ ) as a Subsurface Source of Release to the Atmosphere}

Inventories of iodine-129 have been disposed in burial grounds, released to the ground at liquid discharge sites and are associated with planned disposal of treated waste (i.e., glass logs and solidified secondary waste streams from vitrification processes at the IDF facility). Transport of iodine-129 to the ground surface with subsequent release to the atmosphere is a possibility if gaseous iodine $\left(\mathrm{I}_{2}\right)$ is present in the pore space. The likelihood of gaseous iodine being present will depend on iodine speciation within disposed waste forms, associated leachates and biogeochemical interaction of wastes with subsurface soils. In the case of the disposal of large volume liquid wastes, the buffering capacity of the soil will moderate the often highly caustic or acidic characteristics of the initial waste.

The presence of iodine gas is favorable under acidic conditions but not under alkaline conditions. Iodine under neutral and alkaline conditions forms non-volatile water-soluble iodide $\left(\mathrm{I}^{-}\right)$and iodate $\left(\mathrm{IO}_{3}\right)^{-}$ ions (Greenwood and Earnshaw 1979) (Figure C.1). These ions are indicated to be present in corrosion products of the planned Integrated Disposal Facility (IDF) glassified low-activity tank waste (Pierce et al. 2004). The IDF facility will also be used to dispose secondary waste streams such as grouted solids of off-gas wastes from the vitrification process and other miscellaneous waste streams and future generated solid wastes from Hanford and offsite DOE facilities. Solid waste that is incorporated into a cement waste form generate highly basic $(\mathrm{pH} 12$ to 13.5$)$ leachates and leachates from the Hanford WTP glass waste forms are calculated to be between $\mathrm{pH} 10$ and 11 dependent on glass formulation. Within the IDF, the waste environment is predicted to remain alkaline $(\mathrm{pH} 10)$ through roughly 4,000 years when complete dissolution of the waste form has occurred (Pierce et al. 2004).

The waste disposed to burial grounds and all major liquid discharge sites (e.g., PUREX and REDOX cribs) has been classified as neutral to alkaline including waste streams that were formerly classified as mildly acidic (Last et al. 2004). Thus, iodine from these sources of disposed waste will be in the form of iodide and iodate ions as a result of contact with infiltrating water and iodine-containing leachates reacting with surrounding sediment. The measured range of $\mathrm{pH}$ in leachates of natural (uncontaminated) Hanford sediments is 7.66 to 8.17 . These sediments contain a significant buffering capacity that supports this assumption (Serne et al. 1993). Sediment pore waters are assumed to be mildly oxidizing in an Eh range of +275 to $+400 \mathrm{mV}$ (Figure C.1).

A significant portion of Hanford subsurface sediments is known to be microbially impoverished (Fredrickson et al. 1993). Unsaturated conditions reduce access to essential nutrients resulting in microbial populations that are in induced states of relative inactivity or long-term starvation (Kieft et al. 1993). Therefore, it is assumed that Hanford subsurface microbial populations are small and lack sufficient robustness to produce iodine from the aqueous iodine species present (i.e., iodide and iodate ions).

Based on the above, it is concluded that for Hanford waste in contact with Hanford subsurface sediments, the resulting iodine speciation and microbial state precludes the presence of gaseous $\mathrm{I}_{2}$ in 
waste/sediment pore space in concentrations that could resulting significant transport to the soil surface of Hanford waste sites, which supports the simulation of iodine as a dilute aqueous phase contaminant only.

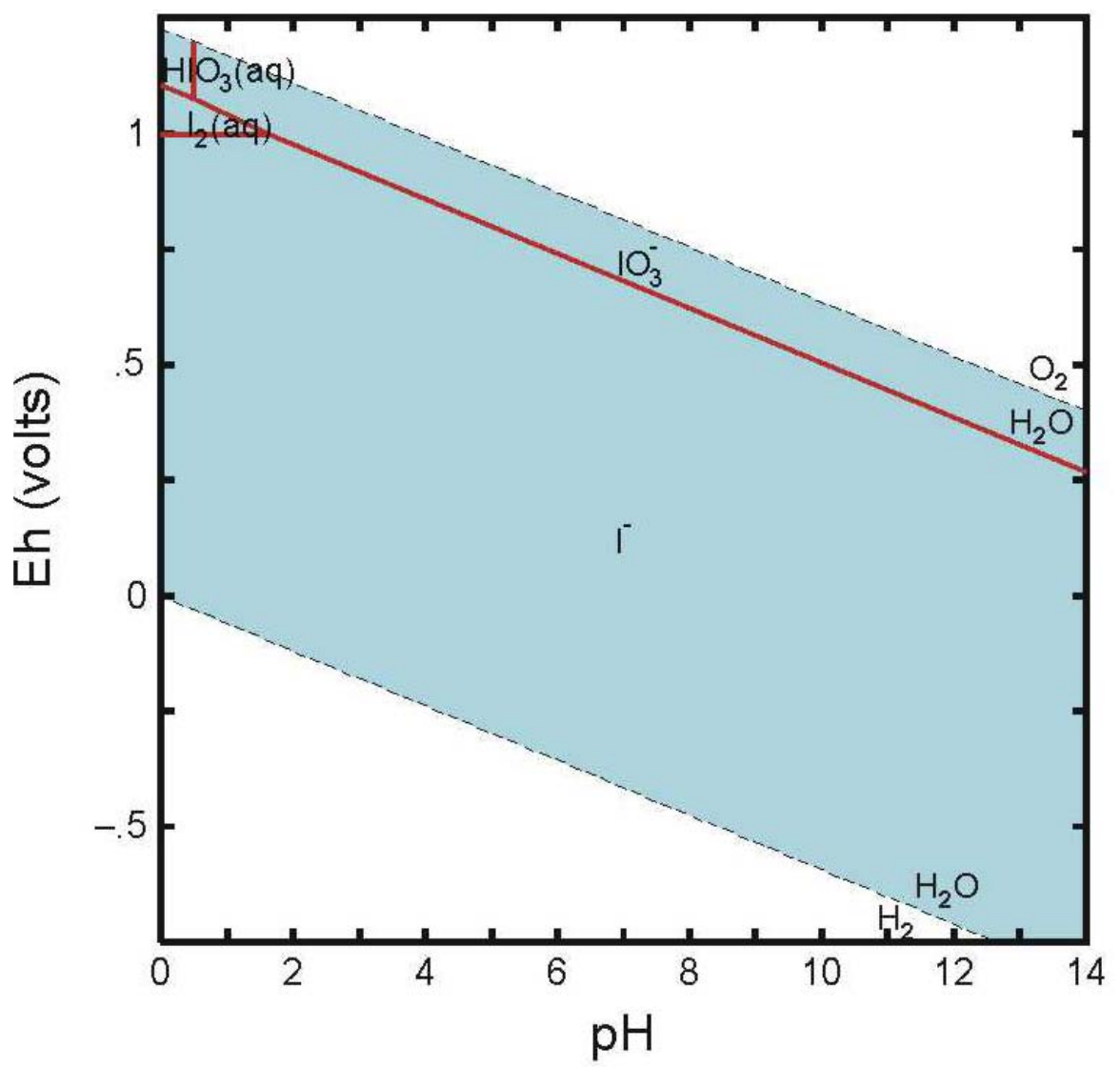

Figure C.1. Eh-pH Diagram (Krupka et al. 2004) Showing Dominant Aqueous Species of Iodine (Diagram was calculated at a total concentration of $1 \times 10^{-8} \mathrm{~mol} / \mathrm{L}$ dissolved iodine at $25^{\circ} \mathrm{C}$.)

\section{C.1 References}

Fredrickson JK, FJ Brockman, BN Bjornstad, PE Long, SW Li, JP McKinley, JV Wright, JL Conca, TL Kieft, and DL Balkwill. 1993. "Microbiological Characteristics of Pristine and Contaminated Deep Vadose Zone Sediments from an Arid Region.” Geomicrobiology Journal. 11:95-107.

Greenwood NN and A Earnshaw. 1979. "Chemistry of the Elements," 2 ${ }^{\text {nd }}$ Edition, ButterworthHeinemann, Oxford.

Kieft TL, PS Amy, FJ Brockman, JK Fredrickson, BN Bjornstad, and LL Rosacker. 1993. "Microbial Abundance and Activities in Relation to Water Potential in the Vadose Zones of Arid and Semiarid Sites." Microbial Ecology. 26:59-78.

Krupka KM, Serne RJ and Kaplan DI. 2004. Geochemical Data Package for the 2005 Hanford Integrated Disposal Facility Performance Assessment. PNNL-13037, Rev. 2, Pacific Northwest National Laboratory, Richland, Washington. 
Last GV, EJ Freeman, KJ Cantrell, MJ Fayer, GW Gee, WE Nichols, BN Bjornstad and DG Horton. 2004. Vadose Zone Hydrogeology Data Package for the 2004 Composite Analysis. PNNL-14702, Rev. 0, Pacific Northwest National Laboratory, Richland, Washington.

Pierce EM, BP McGrail, EA Rodriguez, HT Schaef, KP Saripalli, RJ Serne, KM Krupka, PF Martin, SR Baum, KN Geisler, LR Reed, and WJ Shaw. 2004. Waste Form Release Data Package for the 2005 Integrated Disposal Facility Performance Assessment. PNNL-14805, Pacific Northwest National Laboratory, Richland, Washington.

Serne RJ, JL Conca, VL LeGore, KJ Cantrell, CW Lindenmeier, JA Campbell, JE Amonette, and MI Wood. 1993. Solid-Waste Leach Characteristics and Contaminant-Sediment Interactions, Volume 1: Batch Leach and Adsorption Tests and Sediment Characterization. PNL-8889, Vol. 1, Pacific Northwest Laboratory, Richland, Washington. 
Appendix D

Henry's Law Constants for Carbon-14 (as carbon dioxide) and Iodine-129 (as Iodine) 


\section{Appendix D}

\section{Henry's Law Constants for Carbon-14 (as carbon dioxide) and Iodine-129}

\section{Calculation of Henry's Law Constant for Carbon Dioxide $\left(\mathrm{CO}_{2}\right)$ at $15^{\circ} \mathrm{C}$}

Starting Point: Values of Henry's Law Constant from an Internet database.

The high and low values $\left(4.5 \times 10^{-2}\right.$ and $3.1 \times 10^{-2} \mathrm{~mol} / \mathrm{dm}^{3}$-atm) of 16 values from the database $(3.4,3.4$, $\left.3.4,3.4,3.4,3.4,3.4,3.4,3.4,3.5,3.5,3.5,3.2,3.6 \times 10^{-2} \mathrm{~mol} / \mathrm{dm}^{3}-\mathrm{atm}\right)$ were dropped and I took the average of the remaining 14 values $\left(3.42 \times 10^{-2} \mathrm{~mol} / \mathrm{dm}^{3}\right.$-atm at $\left.25^{\circ} \mathrm{C}\right)$ as the starting point for the calculation.

Equation 4 from the internet data base was used to make the temperature correction from $25^{\circ} \mathrm{C}$ to $15^{\circ} \mathrm{C}$.

$\mathrm{k}_{\mathrm{H}}=\mathrm{k}_{\mathrm{HS}} \mathrm{x} \exp \left(-\Delta_{\mathrm{soln}} H \div R\left(1 / \mathrm{T}_{\mathrm{H}}-1 / \mathrm{T}_{\mathrm{Hs}}\right)\right) \quad$ Equation 4 (Sander 1999, page 3)

where: $\quad \mathrm{k}_{\mathrm{H}}=$ the Henry's Law constant at the temperature of interest (i.e., $15^{\circ} \mathrm{C}\left[288.15^{\circ} \mathrm{K}\right]$ )

$\mathrm{k}_{\mathrm{HS}}=$ the Henry's Law constant at $25^{\circ} \mathrm{C}\left(298.15^{\circ} \mathrm{K}\right)$

$-\Delta_{\text {soln }} H \div R=$ enthalpy of solution $=2,400$ (internet database, page 57 )

$\mathrm{T}_{\mathrm{H}}=$ temperature of interest (i.e., $15^{\circ} \mathrm{C}$ in this case)

$\mathrm{T}_{\mathrm{HS}}=25^{\circ} \mathrm{C}\left(298.15^{\circ} \mathrm{K}\right)$

Calculation:

$$
\begin{array}{rl}
\mathrm{k}_{\mathrm{H}}=3.42 \times 10^{-2} \mathrm{~mol} / \mathrm{dm}^{3}-\mathrm{atm} & x \exp (-2,400(1 / 288.15-1 / 298.15) \\
& x \exp (-2,400(0.0034704147-0.0033540164)) \\
& x \exp (-2,400(0.0001163983) \\
& x \exp (-0.27935592) \\
& x 0.7562706834=2.5864457374 \times 10^{-2} \mathrm{~mol} / \mathrm{dm}^{3}-\mathrm{atm}
\end{array}
$$

Conversion to $\mathrm{mol} / \mathrm{m}^{3}-\mathrm{Pa}$

$$
\begin{aligned}
\mathrm{k}_{\mathrm{H}} & =2.5864457374 \times 10^{-2} \mathrm{~mol} / \mathrm{dm}^{3}-\mathrm{atm} \times 1 \mathrm{dm}^{3} / 10^{-3} \mathrm{~m}^{3} \times 1 \mathrm{~atm} / 101325 \mathrm{~Pa} \\
& =25.5262347633 \times 10^{-5} \mathrm{~mol} / \mathrm{m}^{3}-\mathrm{Pa}
\end{aligned}
$$

Conversion to $\mathrm{Pa}-\mathrm{m}^{3} / \mathrm{mol}$

$$
\mathrm{k}_{\mathrm{H}}=1 / 0.255262347633 \times 10^{-3} \mathrm{~mol} / \mathrm{m}^{3}-\mathrm{Pa}=\mathbf{3 , 9 1 7 . 5 3 8} \mathbf{P a}-\mathbf{m}^{3} / \mathbf{m o l}
$$




\section{Calculation of Henry's Law Constant for Iodine $\left(\mathrm{I}_{2}\right)$ at $15^{\circ} \mathrm{C}$}

Starting Point: Values of Henry's Law Constant from an Internet database.

The high and low values $\left(3.3\right.$ and $1.1 \mathrm{~mol} / \mathrm{dm}^{3}$-atm) of four values from the database $(3.1,3.3,1.1$, $\left.3.0 \mathrm{~mol} / \mathrm{dm}^{3}-\mathrm{atm}\right)$ were dropped and I took the average of the remaining two values $\left(3.05 \mathrm{~mol} / \mathrm{dm}^{3}-\mathrm{atm}\right.$ at $25^{\circ} \mathrm{C}$ ) as the starting point for the calculation.

Equation 4 from the internet database was used to make the temperature correction from $25^{\circ} \mathrm{C}$ to $15^{\circ} \mathrm{C}$.

$\mathrm{k}_{\mathrm{H}}=\mathrm{k}_{\mathrm{HS}} \mathrm{x} \exp \left(-\Delta_{\text {soln }} H \div R\left(1 / \mathrm{T}_{\mathrm{H}}-1 / \mathrm{T}_{\mathrm{HS}}\right)\right) \quad$ Equation 4 (Sander 1999, page 3)

where: $\quad \mathrm{k}_{\mathrm{H}}=$ the Henry's Law constant at the temperature of interest (i.e., $15^{\circ} \mathrm{C}\left[288.15^{\circ} \mathrm{K}\right]$ )

$\mathrm{k}_{\mathrm{HS}}=$ the Henry's Law constant at $25^{\circ} \mathrm{C}\left(298.15^{\circ} \mathrm{K}\right)$

$-\Delta_{\text {soln }} H \div R=$ enthalpy of solution $=4,500$ (internet database, page 11 )

$\mathrm{T}_{\mathrm{H}}=$ temperature of interest (i.e., $15^{\circ} \mathrm{C}$ in this case)

$\mathrm{T}_{\mathrm{HS}}=25^{\circ} \mathrm{C}\left(298.15^{\circ} \mathrm{K}\right)$

Calculation:

$$
\begin{array}{rl}
\mathrm{K}_{\mathrm{H}}=3.05 \mathrm{~mol} / \mathrm{dm}^{3}-\mathrm{atm} & \mathrm{x} \exp (-4,500(1 / 288.15-1 / 298.15) \\
& x \exp (-4,500(0.0034704147-0.0033540164)) \\
& x \exp (-4,500(0.0001163983) \\
& x \exp (-0.523792350) \\
& x 0.592270188=1.8064240726 \mathrm{~mol} / \mathrm{dm}^{3}-\mathrm{atm}
\end{array}
$$

Conversion to $\mathrm{mol} / \mathrm{m}^{3}-\mathrm{Pa}$

$$
\mathrm{k}_{\mathrm{H}}=1.8064240726 \mathrm{~mol} / \mathrm{dm}^{3}-\mathrm{atm} \times 1 \mathrm{dm}^{3} / 10^{-3} \mathrm{~m}^{3} \text { x } 1 \mathrm{~atm} / 101325 \mathrm{~Pa}=1782.80194682 \times 10^{-5} \mathrm{~mol} / \mathrm{m}^{3}-\mathrm{Pa}
$$

Conversion to $\mathrm{Pa}-\mathrm{m}^{3} / \mathrm{mol}$

$$
\mathrm{k}_{\mathrm{H}}=1 / 1782.80194682 \times 10^{-5} \mathrm{~mol} / \mathrm{m}^{3}-\mathrm{Pa}=\mathbf{5 6 . 0 9 1} \mathbf{P a}-\mathbf{m}^{3} / \mathbf{m o l}
$$

\section{D.1 Reference}

Sander R. 1999. Compilation of Henry's Law Constants for Inorganic and Organic Species of Potential Importance in Environmental Chemistry (Version 3). Available online at http://www.mpch-mainz.mpg.de/ sander/res/henry.html 


\section{Distribution}

(Distribution is by electronic copy.)

No. of

Copies

3 DOE Office of River Protection

M.E. Burandt

H6-60

R. W. Lober

S.A. Wiegman

6 DOE Richland Operations Office

B. L. Charboneau

A6-33

B. L. Foley

R. D. Hildebrand

J. G. Morse

K. M. Thompson

DOE Public Reading Room

5 CH2M HILL Hanford Group, Inc.

M. Connelly

H6-03

J. G. Field

J. G. Kristofzski

F. M. Mann

W. J. McMahon

3 Washington Closure

K. R. Fecht

H4-21

E. T. Feist

S. G. Weiss

2 Fluor Federal Services

R. Khaleel

R. J. Puigh

E6-17

E6-17

6 Fluor Hanford, Inc.

B. A. Austin

J. V. Borghese

L. R. Fitch

B. H. Ford

T. W. Fogwell

J. Hoover
No. of

Copies

47 Pacific Northwest National Laboratory

R. L. Aaberg K3-54

M. P. Bergeron K9-36

B. N. Bjornstad K6-81

C. A. Brandt K9-04

R. W. Bryce (5) E6-35

A. L. Bunn K6-85

K. J. Cantrell K6-81

D. W. Engel K5-12

P. W. Eslinger K6-04

J. C. Evans, Jr. K6-96

M. J. Fayer K9-33

E. J. Freeman K9-36

V.L. Freedman K9-36

M. D. Freshley K9-33

G. W. Gee K9-33

T. J. Gilmore K6-96

D. G. Horton K6-81

C. T. Kincaid K9-33

G. V. Last (5) K6-81

C. A. LoPresti K5-12

B. A. Napier K3-54

W. J. Martin K6-81

T. B. Miley K6-04

C. J. Murray K6-81

I. C. Nelson K3-54

W. E. Nichols K9-33

B.E. Opitz K6-75

G. W. Patton K6-75

C. L. Rakowski K9-33

J. V. Ramsdell, Jr K3-54

R. G. Riley K6-96

M. L. Rockhold K9-36

P. A. Scott K9-46

R. J. Serne P7-22

D. L. Strenge K3-54

P. D. Thorne K9-33

M. D. Williams K6-96

S. K. Wurstner K9-36

Hanford Technical Library $\quad$ H2-53 